\title{
Environmental Characterization of Two Ecologically Distinct Gangetic Oxbow Lakes Using Zooplankton Taxonomic Indices In Ecological Monitoring: A Comparative Approach
}

\section{Suman Kumari}

Indian Council of Agricultural Research-Central Inland Fisheries Research Institute

\section{Lianthuamluaia}

Indian Council of Agricultural Research-Central Inland Fisheries Research Institute

\section{U.K. Sarkar ( $\square$ uksarkar1@gmail.com )}

Indian Council of Agricultural Research-Central Inland Fisheries Research Institute

\section{P. Mishal}

Indian Council of Agricultural Research-Central Inland Fisheries Research Institute

\section{G. Karnatak}

Indian Council of Agricultural Research-Central Inland Fisheries Research Institute

D. K. Meena

Indian Council of Agricultural Research-Central Inland Fisheries Research Institute

\section{K. M. Sandhya}

Indian Council of Agricultural Research-Central Institute of Fisheries Technology

\section{A. Hassan}

Indian Council of Agricultural Research-Central Inland Fisheries Research Institute

\section{A. K. Jaiswar}

Indian Council of Agricultural Research-Central Institute of Fisheries Education

\section{A. P. Sharma}

G. B. Pant University of Agriculture \& Technology

B. K. Das

Indian Council of Agricultural Research-Central Inland Fisheries Research Institute

\section{Research Article}

Keywords: Oxbow lake, trophic state index, mTSIROT, mTSIC, fisheries management

Posted Date: December 1st, 2021

DOI: https://doi.org/10.21203/rs.3.rs-1016899/v1

License: (c) (i) This work is licensed under a Creative Commons Attribution 4.0 International License. Read Full License 


\section{Abstract}

In recent years closed and seasonally open oxbow lakes and river floodplains are subjected to eutrophication due to disconnection from river that compromises the hydro-ecological functions. This requires systematic studies to assess the ecological health of the water bodies using different indices and suggest appropriate strategies to manage the resources. The zooplanktons are closely link with surrounding environment throughout their life cycles and change rapidly in their growth and population when changes occurs in the surrounding, hence act as potential indicator of eutrophication. The present study examined the assemblage pattern of zooplankton community and trophic state of two ecologically distinct oxbow lakes based on eco-hydrological characteristics and community structure of rotifers and planktonic crustaceans seasonally over a period of 2 years. Comprehensive trophic state index (mTSI), rotifer trophic state index (mTSI $\mathrm{ROT})$ and Crustacean based indices $\left(\mathrm{TSI}_{\mathrm{CR}}\right)$ were used to assess the degree of eutrophication. The Kruskal-Wallis test confirmed the heterogeneity of the eco-hydrological factors between the oxbow lakes. A total of 68 zooplankton species were identified of which rotifers (69\%), cladocerans (18\%), copepods (3\%), ostacods (3\%) and protozoans (7\%). Seasonal fluctuation of relative abundance and frequency of species in both lakes have been well presented. Both lakes showed transition from high meso-eutrophic to moderately eutrophic state with mTSI, mTSIrot and mTSIcr values of $54.90 \pm 11.71$ and $56.95 \pm 15.64$, $59.55 \pm 4.54$ and $60.26 \pm 4.48,55.79 \pm 4.76$ and $60.00 \pm 4.03$ in Khalsi (seasonally open) and Akaipur (closed) respectively. The Canonical Correspondence analysis (CCA) revealed water quality parameters comparison $\mathrm{NO}_{3}{ }^{-} \mathrm{N}$, water temperature and pH have contributed more in enhancement of abundance of eutrophication indicator species Brachionus and Keratella. The TSIs values indicated a prompt aquaculture fisheries management measures like stocking of planktivorous fish (Labeo catla and Puntius sp.) for both the lakes before they reach in plunged state at which their restoration might become a challenge. An overview of worldwide use of rotifer and crustacean based indices in assessment of TSI has also been synthesized. The use of these zooplankton indices to evaluate the trophic status of the ecologically distinct lakes is highly recommended for water quality assessment and management. Based on this study strategies could be developed to plan and manage floodplain oxbow lakes for fisheries enhancement programme as well as as conservation of biodiversity.

\section{Introduction}

The oxbow lakes are characterized by shallow depth, high sediment nutrient, high productivity, well mixing of nutrient (Janseen et al. 2014; Tang et al. 2018, 2019). These lakes offer a plethora of ecosystem services for livelihood and nutritional security to the riparian communities (Sarkar et al. 2020; Das et al., 2021). These provide safety from natural calamities, serve as habitat for larval rearing, nutrient recycling, water for domestic and irrigation purpose, fishing activities and also considered as "Kidney of ecosystem" due to its efficient sinking capacity to inhale major agricultural runoff (Sarma and Dutta 2012; Meena et al. 2019: Karnatak et al., 2020; Sarkar et al., 2020, 2021a; Sarkar et al., 2021b).

Oxbow lakes, mainly distributed in eastern and northeastern India are important fishery resources. The fisheries in theses lakes are enhanced and managed by integrated resource revival practice based on a combination of fisheries (culture based fisheries, enclosure culture), agriculture, horticulture practices and other jute ratting practices (Chaudhuri et al. 2008; Ghosh and Biswas 2015). Despite of huge potential these water bodies are neglected and being used irrationally. A number of wetland health assessment tools have been applied i.e. macrobenthos based multimetric indices (Meena et al. 2019), phytoplankton indices (Roshith et al. 2018), water quality index (WQI) (Sharma and Bora, 2020), biomonitoring and bioassessment (Sanyal et al., 2015), fish assemblage and fisheries (Sandhya et al., 2016; Sandhya et al., 2019) etc. They have limitations in terms of real time application such as high fluctuations due to climatic and water quality factors. Anthropogenic pressure resulting from agriculture and industrial developmental activities have accelerated degree of eutrophication of freshwater ecosystem worldwide (Junk et al. 2014). Different types of bioindicator are widely used to assess the aquatic ecosystem health using physical, chemical and biological parameters comprehensively (Oh et al. 2017). Trophic state is one of the most important characteristics to classify nutritional load of an aquatic ecosystem (Jekatierynczuk-Rudczyk et al., 2014; Dembowska et al., 2015; Ejsmont-Karabin et al., 2016; Wen et al., 2017; Smaoune et al., 2020). Various environmental factors are applied to measure the trophic status of a lake. One of the most widely used

Page 2/27 
trophic status indices for classifying lakes based on total phosphorus (TP), Sechhi depth (SD) and concentration of Chl a is Carlson trophic status index (Carlson and Havens, 2005; Abell et al., 2020). Easiest one is based on SD but its measures is inclined by both algal and non-algal particulate matters. Zooplankton is one of the important biotic component and a sensitive indicator of water quality, vital for maintaining overall ecosystem productivity and stability of food web (Branco et al., 2002; Kumari et al., 2017; Doukhandji and Arab, 2017; Tang et al. 2019; Smaoune et al., 2020). Trophic status of lakes based on zooplankton such as Rotifers and Crustaceans have been widely used to assess degree of eutrophication in shallow lakes worldwide (Ejsmont-Karabin, 2012; Jekatierynczuk-Rudczyk et al., 2014; Dembowska et al., 2015; EjsmontKarabin et al., 2016; Smaoune et al., 2020) and found promising in assessing trophic status of lake.

Although, several reports are available on zooplankton based diversity indices including abundance, community structure from India (Ganesan and Khan 2008; Sharma 2009, 2011; Sharma and Sharma 2012) and Bangladesh (Biswas and Panigrahi 2015), however, studies limited to the diversity indices for the lakes. A few studies have attempted relation between species richness and assemblage pattern based on macrozoobenthos as well as rotifers to evaluate the wetland health (Kumari et al. 2017; Meena et al. 2019; Ejsmont-Karabin, 2012; Dembowska et al., 2015), crustacean (JekatierynczukRudczyk et al., 2014; Xiong et al., 2016). Therefore, in the present study Rotifer trophic state index (TSI ROT) and crustacean trophic status index $\left(\mathrm{TSI}_{\mathrm{CR}}\right.$ ) developed by Ejmont-Karabin (2012) and modified by Ejsmont-Karabin and Karabin (2013) respectively have been used to estimate ecological quality standard of the two different type of shallow open water bodies. This is promising tool in management of lake, understanding about the trophic status and features of lake can been ascertain.

Rotifer and crustaceans based indices for evaluating the degree of eutrophication and relationship of index with environmental factors are promising for shallow lakes. In the view of above, the present investigation was an attempt to determine spatio-temporal patterns and trends of physico-chemical factors by perusal of zooplankton structured taxonomic indices for revealing spatiotemporal dynamics mediated intensity of eutrophication in two lower Gangetic Oxbow lakes. Thus, lake managers and policy makers to develop guidelines for ecosystem based fisheries management approach for oxbow lakes could utilize outcomes of the study.

\section{Materials And Methods}

\subsection{Study area}

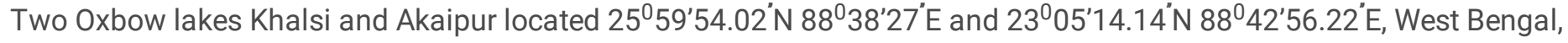
India, respectively (Fig. 1) were selected for study during March 2014- February 2016. Major activities in the catchments of both lakes include; intensive agriculture, habitat for birds, cattle and orchards. These lakes are subjected to culture based fisheries management practices involving stocking of both indigenous and exotic carp seed to provide livelihood support to the 500 and 300 fishers families, respectively (Meena et al., 2019). Both the lakes are located in the lower Gangetic deltaic regions that subjected to the influence of runoff from agricultural land and domestic wastes, silt materials from the catchment due to jute retting, bathing, washing etc. Both the selected lakes are ecologically distinct. Akaipur oxbow lake has lost its perennial connectivity with the flushing channel, while Khalsi oxbow lake still maintains a feeble connectivity with the adjacent rivulet facilitating annual flushing. Dominant submerged macrophytes (Hydrilla verticillata, Ceratophyllum demersum, Vallisneria sp. and floating aquatic vegetations (Eichhornia crassipes, Pistia stratiotes, Nelumbo nucifera, Salvinia molesta, Lemna etc.) have occupied a greater part of Khalsi wetland (40-45\%) distinguishing it from Akaipur, where only sporadic occurrence of aquatic plants was noticed (10-15\%) during the study period. Floating and submerged macrophyte is providing setleter and breeding habitat for many small indigenous fish species in lakes. Water Framework Directive (WFD) has provided guidelines for standard sampling frequency to effectively monitor biotic and abiotic variables of a lake (EC, 2000). The sampling frequency to address the seasonal variability and inter-annual changes are followed as per guidelines of WFD.

\subsection{Plankton data collection and analysis}


The sampling protocol for zooplankton was followed as prescribed by Sharma and Sharma (2012) respectively. Taxonomic identification to the lowest possible taxon using standard keys was carried out following standard literature Koste (1978), Battish (1992), Segers (1995) and Nogrady \& Segers (2002) for rotifers Edmondson (1959), Victor and Fernando (1979), Sehgal (1983), Benzie (2005) and Dussart Defaye (2001) for cladoceans and copepods. Verification and confirmation of taxonomic nomenclature was follows for rotifers International Commission on Zoological Nomenclature (http://iczn.org/lan/rotifer), the Cladocerans (Kotov et al. 2013) and Copepods (Walter \& Boxshall 2018). Abundance of zooplankton was expressed as ind/l. Aliquot of $5 \mathrm{ml}$ sample out of $50 \mathrm{ml}$ sample $(50 \mathrm{ml}$ sample concentrated from 5 litres of lake water) were taken randomly after mixing, used for counting in a Sedgewick-Rafter chamber under an inverted microscope (Zeiss-Winkel) .

Biovolumes of zooplankton were assessed following equations based on geometrical formulae best fitted for each body shape (Ruttner-Kolisko, 1977). Thirty organisms of each selected species were selected randomly of same taxon, length, width and height were measured and best fitted geometrical shape formulae were applied. Biovolume of each taxon was converted to fresh weight assuming a specific density of $\left(1 * 10^{-6}\right)$. The fresh weight (FW) was later converted to dry weight (DW) (Schindler and Noven 1971; Bottrell et al. 1976). Biomass of ostracods was calculated following Lehette and Hernández-León (2009). Biovolume of Copepod nauplii were assumed $0.400 \mu \mathrm{g}$ as suggested by Hawkins and Evans (1979). Zooplankton biomass calculated by multiplying wet weight of individual zooplankton with abundance. Phytoplankton biomass was assessed based on chlorophyll a estimation following Vörös and Padisák (1991).

\subsection{Environmental factors}

For each site three environmental parameters such as Water temperature, $\mathrm{pH}$, conductivity was measured using a multiparameter pcstestr 35 (Eutech) in situ:, water transparency was measured by using Secchi-disc. Dissolved oxygen were measured following modified Winkler's method (Strickland and Parsons 1972). The dissolved inorganic nutrients $\left(\mathrm{NO}_{3}{ }^{-} \mathrm{N}\right.$ and $\mathrm{PO}_{4}{ }^{-} \mathrm{P}$ ), total alkalinity and total hardness were analysed in laboratory following standard methods (APHA, 2005). For chlorophyll a (Chl a) measurement standard spectrophotometric method (HACH Spectrophotometer, DR 2800, Germany) was used (APHA, 2005).

To determine the ecological indices, number of zooplankton taxa present in each season was included in calculation excluding copepod nauplii and unidentified zooplankton. The commonly used index for biological system was ShannonWiener diversity index $\left(\mathrm{H}^{\prime}\right)$, computed to characterize species diversity of zooplankton community. Shannon-Wiener diversity index was used both for comparing two distinct water bodies on temporal and spatial scale and to evaluate the health of water bodies. Index value greater than 3 indicates clean water while values in the range of 1-3 are indicates moderate pollution (Mason 1996).

Species diversity and homogeneity were calculated using the Shannon-Wiener diversity index H' (Shannon and Wiener, 1949) using the following equations:

$$
\mathrm{H}^{\prime}=-\sum_{\mathrm{i}} \mathrm{Pi}(\ln \mathrm{Pi})
$$

Where, $\mathrm{P} i$ is the probability of the $\mathrm{i}^{\text {th }}$ species

The Margalef's richness index (Margalef, 1958) indicates species richness computed by considering number of species.

$$
\mathrm{D}=(\mathrm{S}-1) / \ln \mathrm{N}
$$

Where, $\mathrm{D}=$ Margalef's richness index $\mathrm{S}=$ number of species and $N=$ Total number of individuals 
Evenness index J' (Pielou, 1966), which indicates the degree of evenness of distribution of species in a sample, was determined by following formula

$$
\mathrm{J}^{\prime}=\mathrm{H}^{\prime} / \ln (\mathrm{S})
$$

Where, $H^{\prime}=$ Shannon diversity index and $\mathrm{S}=$ total number of species in a sample, across all samples in database.

The numeric trophic state index (TSI) was used for qualitative assessment of trophic states for the lakes (Carlson 1977 and Adamovich et al. 2016). The wetland trophic status classified on a numerical scale between 0-100 is given in Table 1.

Table 1

The topographic details and land use pattern of Oxbow lakes

\begin{tabular}{|c|c|c|}
\hline Information & Khalsi & Akaipur \\
\hline Area of lakes $(\mathrm{Ha})$ & 65 & 28 \\
\hline Coordinate & $25^{0} 59^{\prime} 54.02^{\prime \prime} \mathrm{N} 88^{0} 38^{\prime} 27^{\prime E}$ & $23^{0} 05^{\prime} 14.14^{\prime N} 88^{0} 42^{\prime} 56.22^{\prime \prime} \mathrm{E}$ \\
\hline Bioclimate & Semi-Aride & Semi-Aride \\
\hline Pre-monsoon season & March-May & March-May \\
\hline Monsoon season & June-August & June-August \\
\hline Post-monsoon & September-November & September -November \\
\hline Winter & December-February & December-February \\
\hline Mean depth (cm) & 177 & 160 \\
\hline Managed by society & KhalsiUdvastuMatsyjiviSamanvayaSamittee Ltd & $\begin{array}{l}\text { AkaipurDwarvasini Fishermen } \\
\text { Cooperative Society Ltd }\end{array}$ \\
\hline River connectivity & Icchamati river & Ganga river \\
\hline Water salinity & Freshwater & Freshwater \\
\hline $\begin{array}{l}\text { Connectivity with river } \\
\text { channel }\end{array}$ & Seasonally open & Closed \\
\hline Macro-vegetation & Floating, submersed and marginal & Floating, submersed and marginal \\
\hline Water use & $\begin{array}{l}\text { Irrigation, Fisheries, Domestic, Cattle bathing, } \\
\text { washing and Jute rating }\end{array}$ & $\begin{array}{l}\text { Fisheries, Cattle bathing, washing and } \\
\text { Jute rating }\end{array}$ \\
\hline $\begin{array}{l}\text { Fisheries } \\
\text { management }\end{array}$ & Culture based fisheries, enclosure culture & $\begin{array}{l}\text { Culture based fisheries, enclosure } \\
\text { culture }\end{array}$ \\
\hline \multirow[t]{2}{*}{ Dominant species } & Small Indigenous fish & Small Indigenous fish \\
\hline & Pethia sp. Puntius sp. Chanda sp. & Pethia sp. Puntius sp. Chanda sp. \\
\hline
\end{tabular}

$\mathrm{mTSI}=\left(\mathrm{TSI} \mathrm{Chl-a}_{\mathrm{a}}+\mathrm{TSI} \mathrm{TP}_{\mathrm{TS}}+\mathrm{TSI}_{\mathrm{SD}}\right) / 3$

The individual trophic state index (TSI) of Chlorophyll a (Chl-a), total phosphorus (TP) and Secchi disk transparency (SD) were calculated as follows.

(1) $\mathrm{TSI}_{\mathrm{Chl}-\mathrm{a}}=9.76 \mathrm{ln}(\mathrm{Chl}-\mathrm{a})+30.91$ 
(2) $\mathrm{TSI}_{\mathrm{TP}}=14.43 \ln (\mathrm{TP})+4.15$

(3) $\mathrm{TSI}_{\mathrm{SD}}=-14.39 \mathrm{In}(\mathrm{SD})+59.91$

Rotifer is one of the biotic components, which is used as an indicator of aquatic ecological health (Ejmont-Karabin, 2012). Rotifer community structure have been used for rotifer trophic status index $\left(\mathrm{TSI}_{\mathrm{ROT}}\right.$ ) by following equations given by (Ejmont-Karabin, 2012)

(1) $\mathrm{TSI}_{\mathrm{ROT} 1}=5.38 \mathrm{In}(\mathrm{Nr})+19.28$; where $\mathrm{Nr}$ number of rotifer (ind/l)

(2) $\mathrm{TSI}_{\mathrm{ROT} 2}=5.38 \mathrm{ln}(\mathrm{B})+64.47$; where $\mathrm{B}$ biomass of rotifer $(\mathrm{mg} \mathrm{ww} / \mathrm{l})$

(3) $\mathrm{TSI}_{\mathrm{ROT} 3}=3.85(\mathrm{~B} / \mathrm{Nr})^{-0.318}$

(4) $\mathrm{TSI}_{\mathrm{ROT} 4}=0.144 \mathrm{TECTA}+54.8$; percentage of spineless form (tecta) in abundance of Keratella cochlearis

(5) $\mathrm{TSI}_{\mathrm{ROT} 5}=0.203 \mathrm{IHT}+40.0$; number of species contributed to the high trophic status indicator group

The mean value of TSI ( $\mathrm{mTSI}_{\mathrm{ROT}}$ ) obtained from of above five equation is used as an indicator of Ecological status of lakes. Crustacean based indices ( $\mathrm{TSI}_{\mathrm{CR}}$ ) was developed by Ejsmont-Karabin \& Karabin (2013) for estimation of Crustacean based trophic status indices has followed for Trophic index of lakes is given below;

(6) $\mathrm{TSI}_{\mathrm{CR} 1}=25.5 \mathrm{Nr}^{0.142}$; where Nr number of crustacean abundance (ind/I)

(7) $\mathrm{TSI}_{\mathrm{CR} 2}=57.6 \mathrm{~B}^{0.081}$; where $\mathrm{B}$ total wet cyclopoid biomass $(\mathrm{mg} / \mathrm{l})$

(8) $\mathrm{TSI}_{\mathrm{CR} 3}=40.9 \mathrm{CB}^{0.097}$; percentage of cyclopoid biomass in the total crustacean biomass

(9) $\mathrm{TSI}_{\mathrm{CR} 4}=58.3(\mathrm{CY} / \mathrm{CL})^{0.071} ; \mathrm{CY} / \mathrm{CL}$ : ratio of cyclopoids $(\mathrm{CY})$ to cladoceran biomass $(\mathrm{CL})$

(10) $\mathrm{TSI}_{\mathrm{CR} 5}=5.08 \mathrm{Ln}(\mathrm{CY} / \mathrm{CA})+46.6$; ratio of cyclopoids $(\mathrm{CY})$ to calanoid biomass $(\mathrm{CA})$

\subsection{Statistical analysis}

Statistical analysis was applied on dataset of environmental and biological factors to the know the spatio-temporal variability of the studied lakes. The Spearman's bivariate correlation test was performed to explain the level of significant relationship among the environmental factors. Krushkal- Wallis test at the level of significance (5\%) were used for analysis of difference among the physico-chemical water quality parameters between the oxbow lakes using SPSS 16.0. Canonical correspondence analysis (CCA) is well known multivariate method to explain the biological identified assemblage and environmental factors. The statistical analysis was performed in R (R Development Core Team 2018).

\section{Results}

\subsection{Variations among environmental factors}

During the study period, the physical and chemical water quality parameters were obtained for two years, the stations of each seasons were grouped and presented in the form of average value for both the lakes separately. Correlogram of environmental variables based on their relationship depicted in Figure 2. The size of a circle indicates the strength of the correlation and the colour indicates the direction of correlation (that is, blue $=$ positive, orange to red $=$ negative). Only significant correlations $(P<0.01)$ are shown in the Figure 2. The correlation statistical analysis shows highly correlated between the variables EC and Alk $(P<0.01, r=0.85)$, between EC and Hard $(P<0.01, r=0.83)$, Hard and Temp $(P<0.01, r=$ 
0.73). It was also found that $\mathrm{PO}_{4}{ }^{-} \mathrm{P}$ was positively correlated with Depth $(P<0.01, r=0.66)$, with Hard, Alk and EC. On the other hand, $\mathrm{N}: \mathrm{P}$ were strongly negatively correlated with $\mathrm{PO}_{4}{ }^{-} \mathrm{P}(\mathrm{P}<0.01, \mathrm{r}=-0.72)$.

The spatio-temporal variations of each physico-chemical parameter for the both oxbow lakes are given in the Figure 3 . The physic-chemical parameters measured for each lakes reflect a spatial difference in majority of variables have been confirmed by performing Kruskal-Wallis test $(\mathrm{P}<0.05)$ except Temp, Depth, $\mathrm{Chl}$ a, $\mathrm{NO}_{3}{ }^{-} \mathrm{N}$ and N:P $(\mathrm{P}>0.05)$. The average water temperature (Temp) recorded during the study indicated that there is no spatial significant difference between two lakes $(P=0.51>0.05)$. The maximum average value $\left(34.4^{\circ} \mathrm{C}\right)$ was recorded during PRM $2015-16$ in Khalsi lake while minimum average value $\left(22.3^{\circ} \mathrm{C}\right)$ were recorded during WIN 2015-16 in Akaipur lake. The mean value of Depth is variable (P $>0.05$ ) but insignificant. The maximum depth of both the lakes was recorded during MON season of 2015-2016 and minimum during PRM of the same year. The average $\mathrm{Chl}$ a recorded during this study indicate that there is no heterogeneity in two lakes $(P=0.25>0.05)$. The maximum average $\mathrm{Chl}$ a value $(11.6 \mu \mathrm{g} / \mathrm{L})$ was recorded during PRM $2015-16$ in Khalsi lake while minimum average $\mathrm{Chl}$ a value $(1.4 \mu \mathrm{g} / \mathrm{L})$ were recorded during PRM 2014-15 in Akaipur lake. The average value of $\mathrm{NO}_{3}{ }^{-} \mathrm{N}$ and $\mathrm{N}: \mathrm{P}$ recorded in the studies both lakes shows no significant difference $(\mathrm{P}>0.05)$ between the lakes. The minimum N:P ration was recorded during the MON 2015-2016 and minimum $\mathrm{NO}_{3}{ }^{-} \mathrm{N}$ in WIN 2014-2015 in Akaipur lake.

The recorded average $\mathrm{pH}$ values throughout the study period are illustration homogeneity in nature $(\mathrm{P}<0.05)$. The minimum average value 7.4 was recorded at the Khalsi lake in PM 2015-2016 and the maximum average value 8.9 was recorded in the Akaipur lake during POM 2015-2016. The results show that EC follows a significant spatial variation $(P<0.05)$ between the lakes. The recorded the highest EC Value $(416 \mu \mathrm{S} / \mathrm{cm})$ during PRM 2015-2016 in Khalsi. The minimum average value of 117 $\mu \mathrm{S} / \mathrm{cm}$ was recorded in WIN 2014-2015 in the Akaipur. The average levels of DO show a very marked spatial variation between the lakes $(P<0.05)$. The highest DO concentration was recorded in WIN season 2014-2015 in both the lakes and minimum in MON 2-15-16. The mean SD levels show a great variation $(P<0.01)$. The Akaipur were recorded very low levels of transparency (SD) in both the years of study during PRM compare to Khalsi in same season. The maximum level in Khalsi was recorded in PM 2014-2015 with $127 \mathrm{~cm}$. our result shows that the Khalsi is more transparent than Akaipur. The variation of Alk (total alkalinity during our study is very remarkable $(P<0.01)$. The minimum average value was recorded in the POM 2014-2015 in Akaipur and maximum PRM 2015-2016 in Khalsi. The average value of Hard (total hardness) shows that there is spatial heterogeneity between the lakes $(P<0.01)$. The highest mean value $(170 \mathrm{mg} / \mathrm{L})$ of Hard was recorded in PRM 2015-2016 in the Khalsi and minimum (34.6 mg/L). The Khalsi recorded very high level of $\mathrm{PO}_{4}{ }^{-} \mathrm{P}$ content than Akaipur during 2014-2015. The mean value of $\mathrm{PO}_{4}{ }^{-} \mathrm{P}$ content significantly varies between the lakes $(\mathrm{P}<0.05)$. The maximum $\mathrm{PO}_{4}{ }^{-} \mathrm{P}$ content was recorded during MON 2015-2016 in Akaipur followed by POM in Khalsi for the same year.

\subsection{Spatio-temporal variation of diversity and community characteristics of zooplankton}

A total of 68 species of zooplankton were identified in the two oxbow lakes; Khalsi (54 species) and Akaipur (45 species), including Rotifera (47 species), Cladocera (12 species), Copepoda (2 orders), Ostracoda (2 species) and Protozoa (5 species). Only 3 species were Filinia longispina, B. fulcatus, Keratella cochlearis of rotifer was recorded throughout the study period. Species richness was recorded more in Khalsi than Akaipur lake. Relative abundance of $B$. fulcatus and $B$. budapestiensis were more than $10 \%$ each while B. budapestiensis is absent in Khalsi lake. K. longiseta was recorded in all seasons except premonsoon in Khalsi lake while absent in Akaipur lake. K. quadrata was found abundant in Akaipur lake where as absent in Khalsi. The maximum 14 specises such as Filinia longispina, Brachionus rubens, $B$. fulcatus, $B$. forficula, Keratella cochlearis, K. tropica, Bosmina longirostris, Polyarthra vulgaris Ceriodaphnia cornuta, Moina branchiate, $M$. micrura, Mesocyclops sp., Phyllodiaptomus sp. and Centropyxis aculeate were commonly found in both the lakes. Polyarthra vulgaris was occasionally recorded in warmer season from premonsoon to postmonsoon and absent in winter.

The 21 species/genera viz. Polyarthra dolicoptera, Filinia longiseta, F. opoliensis, T. longiseta, P. quadricornis, B. Calyciflurous, B. caudatus f. austerogenitus, K. longiseta, K. tropica, Mytilina mucronata, M. ventralis, Lecane ungulate, 
Testudinella patina, Synchaeta sp., A. herricki, Leydigia sp., Cypris sp., Stenocypris sp., Diffugia corona, Vorticella sp. and Colpodia colpodia are recorded only in Khalsi lake with varying abundance and frequency. A total of 10 species /genera viz. K. quadrata, T. cylindrica P. multiappendiculata, Lepadella patella, L. ploenensis L. Iuna, Alona verrucosa, Notholca sp., Asplanchna brightwelli and Diaphanosoma were observed only in Akaipur lake with varying seasonal abundance and frequency (Table 2). Out of 12 species / taxa of cladocerans Ceriodaphnia cornuta, Moina branchiate and M. micrura were recorded few in number during monsoon seasons in Khalsi lake. Mesocyclops sp. and Phyllodiaptomus sp. were recorded throughout the study period but higher abundance during monsoon and pos-tmosoon. Number of naupli was decreased in 2015-16 as compared to 2014-15. 
Table 2

Relative abundance, frequency, and seasonality of rotifers encountered in the different oxbow lakes between April 2014 and March 2016

\begin{tabular}{|c|c|c|c|c|c|c|c|c|c|c|c|}
\hline \multirow{3}{*}{$\begin{array}{l}\text { S.N } \\
\text { PRM }\end{array}$} & \multirow{3}{*}{$\begin{array}{l}\text { Name of Species } \\
\text { MON }\end{array}$} & \multicolumn{5}{|c|}{ Khalsi Oxbow lakes } & \multicolumn{5}{|c|}{ Akaipur Oxbow lakes } \\
\hline & & \multirow{2}{*}{$\begin{array}{l}\text { RA } \\
\text { POM }\end{array}$} & \multicolumn{4}{|c|}{ RFSeasonally } & \multicolumn{5}{|l|}{$\mathrm{RA}$} \\
\hline & & & WIN & PRM & MON & POM & WIN & & eas & Ially & \\
\hline 1. & Scaridium lingicaudum & + & $\mathrm{C}$ & - & - & 0 & + & A & - & $\mathrm{R}$ & - \\
\hline 2. & Polyarthra vulgaris & + & 0 & 0 & 0 & - & + & 0 & 0 & 0 & - \\
\hline 3. & P. multiappendiculata & - & - & - & - & - & + & $\mathrm{R}$ & - & - & A \\
\hline 4. & P. dolicoptera & + & 0 & 0 & - & $\mathrm{F}$ & - & - & - & - & - \\
\hline 5. & Filinia longispina & + & 0 & $\mathrm{R}$ & 0 & 0 & + & 0 & $\mathrm{R}$ & $\mathrm{R}$ & 0 \\
\hline 6. & F. terminalis & + & - & 0 & $\mathrm{~F}$ & 0 & + & $\mathrm{R}$ & $\mathrm{R}$ & $\mathrm{F}$ & $\mathrm{F}$ \\
\hline 7. & F. longiseta & + & - & - & $\mathrm{C}$ & 0 & - & - & - & - & - \\
\hline 8. & F. opoliensis & + & - & - & - & $A$ & - & - & - & - & - \\
\hline 9. & Trichocerca similis & + & - & 0 & C & - & + & - & - & $\mathrm{F}$ & $\mathrm{F}$ \\
\hline 10. & T. longiseta & + & - & - & - & $A$ & - & - & - & - & - \\
\hline 11. & T. cylindrica & - & - & - & - & - & + & - & $\mathrm{R}$ & $A$ & - \\
\hline 12. & T.sp & + & 0 & $\mathrm{R}$ & 0 & $\mathrm{R}$ & - & - & - & - & - \\
\hline 13. & Anuraeopsis fissa & - & - & - & - & - & + & - & - & $A$ & - \\
\hline 14. & Platyias polycanthus & + & 0 & $\mathrm{R}$ & 0 & $\mathrm{R}$ & + & - & $A$ & - & $\mathrm{R}$ \\
\hline 15. & P. quadricornis & - & - & - & - & - & - & - & - & - & - \\
\hline 16. & Cephalodella gibba & + & $\mathrm{R}$ & $\mathrm{F}$ & 0 & - & + & - & - & $A$ & - \\
\hline 17. & Brachionus rubens & + & $\mathrm{R}$ & 0 & $\mathrm{R}$ & 0 & + & - & $\mathrm{C}$ & $\mathrm{R}$ & 0 \\
\hline 18. & B. fulcatus & + & $\mathrm{R}$ & 0 & $\mathrm{R}$ & 0 & ++ & $\mathrm{R}$ & $\mathrm{F}$ & $\mathrm{R}$ & 0 \\
\hline 19. & B. forficula & + & - & 0 & $\mathrm{R}$ & 0 & + & $\mathrm{R}$ & $\mathrm{R}$ & $\mathrm{R}$ & $\mathrm{F}$ \\
\hline 20. & B. budapestiensis & - & - & - & - & - & ++ & C & $\mathrm{R}$ & $\mathrm{R}$ & $\mathrm{R}$ \\
\hline 21. & B. Calyciflurous & + & $\mathrm{R}$ & $\mathrm{F}$ & - & 0 & - & - & - & - & - \\
\hline 22. & B. patulus & + & $\mathrm{F}$ & - & - & $\mathrm{F}$ & + & - & $\mathrm{F}$ & - & 0 \\
\hline 23. & B. quadridentatus & - & - & - & - & - & + & $\mathrm{R}$ & 0 & $\mathrm{R}$ & 0 \\
\hline 24. & B. caudatus $f$. austerogenitus & + & - & 0 & - & $\mathrm{F}$ & - & - & - & - & - \\
\hline 25. & B. caudatus & + & - & 0 & $\mathrm{R}$ & $\mathrm{F}$ & + & 0 & $\mathrm{R}$ & $\mathrm{R}$ & 0 \\
\hline
\end{tabular}

Note:

RF: relative frequency $(A$, abundant with $R F=100-81 \%$; , common with $R F=80-61 \%$; , frequent with $R F=60-41 \%$; occasional with $\mathrm{RF}=40-21 \%$; $\mathrm{R}$, rare with $\mathrm{RF}=20-0 \%$ )

RA: relative abundance (+++with RA $>11 \%,++$ with RA $=6-10 \%$, + with RA $=5-1 \%$ )

PRM: Premonsoon; MON:monsoon; POM:postmonsoon; WIN: winter; - :absent 


\begin{tabular}{|c|c|c|c|c|c|c|c|c|c|c|c|}
\hline \multirow{3}{*}{$\begin{array}{l}\text { S.N } \\
26 .\end{array}$} & \multirow{3}{*}{$\begin{array}{l}\text { Name of Species } \\
\text { B. diversicornis }\end{array}$} & \multicolumn{5}{|c|}{ Khalsi Oxbow lakes } & \multicolumn{5}{|c|}{ Akaipur Oxbow lakes } \\
\hline & & \multirow{2}{*}{$\begin{array}{l}\text { RA } \\
+\end{array}$} & \multicolumn{4}{|c|}{ RFSeasonally } & \multicolumn{5}{|c|}{ RA } \\
\hline & & & $\mathrm{R}$ & 0 & - & $\mathrm{F}$ & + & 0 & - & 0 & $\mathrm{~F}$ \\
\hline 27. & B. angularis & + & - & 0 & - & C & + & - & - & - & A \\
\hline 28. & Keratella cochlearis & + & 0 & $\mathrm{~F}$ & 0 & $\mathrm{R}$ & + & $\mathrm{R}$ & $\mathrm{F}$ & $\mathrm{R}$ & 0 \\
\hline 29. & K. quadrata & - & - & - & - & - & + & 0 & $\mathrm{R}$ & 0 & 0 \\
\hline 30. & K. longiseta & + & - & $\mathrm{R}$ & $\mathrm{F}$ & $\mathrm{F}$ & - & - & - & - & - \\
\hline 31. & K. tropica & + & 0 & 0 & 0 & A & + & - & C & $\mathrm{R}$ & 0 \\
\hline 32. & Mytilina mucronata & + & 0 & 0 & 0 & A & - & - & - & - & - \\
\hline 33. & M. ventralis & + & 0 & 0 & 0 & A & - & - & - & - & - \\
\hline 34. & Monostyla spp. & + & - & 0 & - & C & - & - & - & - & - \\
\hline 35. & Lecaneungulata & + & - & 0 & - & C & - & - & - & - & - \\
\hline 36. & L. bulla & + & - & - & - & A & + & $\mathrm{R}$ & - & - & A \\
\hline 37. & L. ploenensis & - & - & - & - & - & + & - & - & - & A \\
\hline 38. & L. luna & - & - & - & - & - & + & $\mathrm{F}$ & 0 & - & - \\
\hline 39. & L.sp & - & - & - & - & - & + & - & $\mathrm{R}$ & $\mathrm{F}$ & $\mathrm{F}$ \\
\hline 40. & Testudinella patina & + & 0 & - & - & $\mathrm{F}$ & - & - & - & - & - \\
\hline 41. & Lepadella patella & - & - & - & - & - & + & 0 & 0 & - & 0 \\
\hline 42. & L. sp & + & - & - & - & A & - & - & - & - & - \\
\hline 43. & Synchaeta sp. & + & $\mathrm{F}$ & - & - & $\mathrm{F}$ & - & - & - & - & - \\
\hline 44. & Notholca sp. & - & - & - & - & - & + & - & - & 0 & 0 \\
\hline 45. & Asplanchna brightwelli & - & - & - & - & - & + & 0 & - & 0 & 0 \\
\hline 46. & A. herricki & + & - & $\mathrm{F}$ & - & $\mathrm{F}$ & - & - & - & - & - \\
\hline 47. & A. $s p$ & + & $\mathrm{F}$ & - & 0 & 0 & + & 0 & - & 0 & C \\
\hline 48. & Bosmina longirostris & + & 0 & - & 0 & $\mathrm{~F}$ & + & $\mathrm{R}$ & - & 0 & C \\
\hline 49. & B. sp & + & - & - & 0 & C & + & $\mathrm{R}$ & $\mathrm{R}$ & $\mathrm{R}$ & C \\
\hline 50. & Ceriodaphnia cornuta & + & $\mathrm{R}$ & 0 & $\mathrm{~F}$ & $\mathrm{R}$ & + & 0 & - & $\mathrm{R}$ & $\mathrm{F}$ \\
\hline 51. & Moina branchiata & + & - & $\mathrm{R}$ & $\mathrm{R}$ & C & + & - & - & $\mathrm{F}$ & $\mathrm{F}$ \\
\hline 52. & M. micrura & + & $\mathrm{R}$ & 0 & 0 & 0 & + & $\mathrm{F}$ & - & 0 & $\mathrm{~F}$ \\
\hline 53. & Moinodaphnia macleayi & + & - & - & - & A & + & - & - & - & A \\
\hline \multicolumn{12}{|c|}{ Note: } \\
\hline \multicolumn{12}{|c|}{$\begin{array}{l}\text { RF: relative frequency }(A \text {, abundant with } R F=100-81 \% ; C \text {, common with } R F=80-61 \% ; F \text {, frequent with } R F=60-41 \% ; 0 \text {, } \\
\text { occasional with } R F=40-21 \% \text {; rare with } R F=20-0 \%)\end{array}$} \\
\hline \multicolumn{12}{|c|}{ RA: relative abundance $(+++$ with $\mathrm{RA}>11 \%,++$ with $\mathrm{RA}=6-10 \%,+$ with $\mathrm{RA}=5-1 \%)$} \\
\hline \multicolumn{12}{|c|}{ PRM: Premonsoon; MON:monsoon; POM:postmonsoon; WIN: winter; - :absent } \\
\hline
\end{tabular}




\begin{tabular}{|c|c|c|c|c|c|c|c|c|c|c|c|}
\hline \multirow[t]{2}{*}{ S.N } & \multirow[t]{2}{*}{ Name of Species } & \multicolumn{5}{|c|}{ Khalsi Oxbow lakes } & \multicolumn{5}{|c|}{ Akaipur Oxbow lakes } \\
\hline & & RA & & sor & & & RA & & & & \\
\hline 54. & Alona verrucosa & - & - & - & - & - & + & - & $\mathrm{R}$ & $\mathrm{R}$ & C \\
\hline 55. & A. sp. & + & $\mathrm{R}$ & - & - & A & - & - & - & - & - \\
\hline 56. & Leydigia sp. & + & - & - & - & A & - & - & - & - & - \\
\hline 57. & Daphnia lumhottzi & + & - & $\mathrm{R}$ & - & A & + & - & $\mathrm{F}$ & $\mathrm{R}$ & $\mathrm{F}$ \\
\hline 58. & Daphnia sp. & + & - & - & - & A & + & - & - & - & $A$ \\
\hline 59. & Diaphanosoma & - & - & - & - & - & ++ & $\mathrm{F}$ & $\mathrm{R}$ & $\mathrm{R}$ & 0 \\
\hline 60. & Mesocyclops sp. & ++ & $\mathrm{R}$ & $\mathrm{O}$ & $\mathrm{F}$ & $\mathrm{R}$ & + & 0 & $\mathrm{~F}$ & 0 & - \\
\hline 61. & Phyllodiaptomus sp. & ++ & $\mathrm{R}$ & $\mathrm{R}$ & $\mathrm{F}$ & $\mathrm{F}$ & + & $\mathrm{R}$ & $\mathrm{R}$ & 0 & $\mathrm{~F}$ \\
\hline 62. & Cypris sp. & + & - & - & A & - & - & - & - & - & - \\
\hline 63. & Stenocypris sp. & + & $\mathrm{F}$ & - & $\mathrm{F}$ & - & - & - & - & - & - \\
\hline 64. & Stylonychia pustulata & + & 0 & - & C & - & - & - & - & - & - \\
\hline 65. & Centropyxis aculeata & + & 0 & - & C & - & + & $\mathrm{R}$ & - & 0 & C \\
\hline 66. & Diffugia corona & + & - & $\mathrm{R}$ & $\mathrm{F}$ & $\mathrm{F}$ & - & - & - & - & - \\
\hline 67. & Vorticella sp. & + & - & - & - & A & - & - & - & - & - \\
\hline 68. & Colpodia colpodia & +++ & - & - & 0 & C & - & - & - & - & - \\
\hline \multicolumn{12}{|c|}{ Note: } \\
\hline \multicolumn{12}{|c|}{$\begin{array}{l}\text { RF: relative frequency }(A \text {, abundant with } R F=100-81 \% \text {; } C \text {, common with } R F=80-61 \% ; F \text {, frequent with } R F=60-41 \% ; 0 \text {, } \\
\text { occasional with } R F=40-21 \% ; R \text {, rare with } R F=20-0 \%)\end{array}$} \\
\hline \multicolumn{12}{|c|}{ RA: relative abundance $(+++$ with $\mathrm{RA}>11 \%,++$ with $\mathrm{RA}=6-10 \%,+$ with $\mathrm{RA}=5-1 \%)$} \\
\hline
\end{tabular}


Table 3

Numeric scale of trophic status index (TSI) based on

Chl-a, SD, TSI ${ }_{\mathrm{ROT}}$ and $\mathrm{TSI}_{\mathrm{CR}}$ following Tang et al. (2019),

Ejsmont-Karabin\&Karabin (2013) and Ejmont-Karabin

(2012)

\begin{tabular}{|llll|}
\hline SI. No. & TSI & mTSI $_{\text {ROT }}$ & Ecological status \\
\hline 1 & $0-20$ & $<35$ & oligotrophic \\
\hline 2 & $20-30$ & $35-40$ & low mesotrophic \\
\hline 3 & $30-40$ & $40-45$ & high mesotrophic \\
\hline 4 & $40-50$ & $45-50$ & low meso-eutrophic \\
\hline 5 & $50-55$ & $50-55$ & high meso-eutrophic \\
\hline 6 & $55-60$ & $55-60$ & slight eutrophic \\
\hline 7 & $60-70$ & $60-65$ & moderately eutrophic \\
\hline 8. & $>70$ & $>65$ & hyper eutrophic \\
\hline
\end{tabular}

\subsection{Diversity indices}

The result of the various indices such as diversity (Shannon-Wiener H'), richness (Margalef D), evenness (Pielou J') of both lakes varies significantly. The $\mathrm{H}^{\prime}$ ranged from 2.231 (post-monsoon) to 3.315 (winter) with mean value of $2.588 \pm 0.09$ in Khalsi lake and 1.88 (winter) to 2.81 (post monsoon) with mean value $2.426 \pm 0.12$ in Akaipur lake. The species richness (D) value oscillates from 0.79 (winter) to 0.9425 (monsoon) with mean value of $0.86 \pm 0.06$ in Khalsi lake where as in Akaipur lake ranged between 0.72 (winter) to 0.957 (post-monsoon) with mean value of $0.870 \pm 0.11$. Pielou evenness (J') was recorded lowest 0.61 (winter) and highest 0.87 (pre-monsoon) with an average value of $0.71 \pm 0.06$ in Khalsi lake. In Akaipur lake J' value varies from 0.68 (winter) to 0.80 (pre-monsoon) with mean value of $0.74 \pm 0.05$.

\subsection{Degree of eutrophication (TSI)}

Trophic status was calculated based on three water parameters- transparency (sechhi disk depth), total phosphorus, total chlorophyll a and two taxon based rotifer and crustaceans. TSI results show that TSI (Chla) varies significantly 33.57 (premonsoon of 1 st year) - 53.48 (premonsoon of 2 nd year) of study. The value indicated based on presence of chlorophyll a Khalsi lake moving towards higher mesotrophic state from oligotrophic state. In Akaipur lake TSI (Chla) oscillate from 37.14 (premonsoon of 1 st year) - 54.4 (monsoon of 1 st year), indicated similar to Khalsi lake. The value of TSI (SD) varies from 53.03 (post monsoon of 1st year) to 70.51 (premonsoon of 2nd year) in Khalsi lake, while in Akaipur lake varies from 63.09 (postmonsoon of 1st year) -82.51 (premonsoon of 2nd year). The TSI calculated based on total phosphorsu present in lake TSI (TP) ranged from 52.18 (premonsoon of 1st year) to 75.43 (post monsoon of 2nd year) (Fig. 4a and b). The mTSI insignificantly varied from $47.28 \pm 10.28$ to $62.53 \pm 13.14$ in Khalsi and $51 \pm 16.23$ to $62.91 \pm 15.06$ in Akaipur. The mTSI values indicated that both the lakes are inclined towards moderately eutrophication (Table 1).

The $\mathrm{mTSI}_{\mathrm{ROT}}$ values were varied $56.41 \pm 2.38$ to $62.70 \pm 6.70$ and $58.73 \pm 2.10$ to $61.80 \pm 6.87$ in Khalsi and Akaipur lakes, respectively (Fig. $4 \mathrm{a} \& \mathrm{~b}$ ). The calculated $\mathrm{mTSI}_{\mathrm{ROT}}$ values indicated both the lakes were to be transition stage of slightly eutrophic to moderately eutrophic condition. The $\mathrm{mROT}_{\mathrm{CR}}$ value was varied $49.26 \pm 3.44$ to $62.32 \pm 6.08$ and $52.63 \pm 5.68$ to $67.38 \pm 2.38$ in Khalsi and Akaipur lakes, respectively (Fig. 4a\&b). The variation $\mathrm{mROT}_{\mathrm{CR}}$ in Akaipur lake was ranged greater varies from meso-eutrophic to hyper eutrophic condition. Single peak value in $\mathrm{BROT}_{\mathrm{CR}}$ was observed during monsoon of 2014-2015. 
Analyses of Pearson's correlations among taxonomic diversity indices $\mathrm{D}, \mathrm{J}, \mathrm{H}$ ', and trophic status indices $m T S I_{\mathrm{ROT}}$ and $\mathrm{mTSI}_{\mathrm{CR}}$ with environmental parameters were given in the Table 4. The $\mathrm{mTSI} \mathrm{ROT}_{\mathrm{T}}$ of both lakes were found to exhibit a significantly positively correlation with $\mathrm{PO}_{4}{ }^{-} \mathrm{P}$ and $\mathrm{Chl}$ a and significantly negatively correlated with $\mathrm{N}: \mathrm{P}$ and DO concentration. The $\mathrm{mTSI}_{\mathrm{CR}}$ were also significantly negatively with $\mathrm{N}: \mathrm{P}$ and positively with $\mathrm{PO}_{4}{ }^{-} \mathrm{P}$ and $\mathrm{Chl}$ a correlated in both lakes. This indices were also negatively significantly correlated with Temp and DO in Khalsi lake and insignificant in Akaipur lake. The Shannon Wiener $\left(\mathrm{H}^{\prime}\right)$ is significantly positively correlated with DO concentration in both lakes but negatively with $\mathrm{PO}_{4}{ }^{-} \mathrm{P}$ and $\mathrm{Chl}$ a concentration. Pielou's eveness $(\mathrm{J})$ of both the lakes were highly significantly negatively correlated with water depth and positively with EC. The significance of Margalef index (D) of both lakes were highly variable.

Table 4

The Pearson correlations between taxonomic indices (Margalef index (D), Pielou's eveness $(J)$, Shannon Wiener $\left(H^{\prime}\right)$, $\mathrm{mTSI}_{\mathrm{ROT}}, \mathrm{mTSI}_{\mathrm{CR}}$ and environmental factors. ( ${ }^{*} \mathrm{P}<0.05$ and $* * \mathrm{P}<0.01$ )

\begin{tabular}{|c|c|c|c|c|c|c|c|c|c|c|}
\hline & Khalsi Ox & ow Lake & & & & Akaipur C & bow Lake & & & \\
\hline & $\mathrm{mTSI}_{\mathrm{ROT}}$ & $\mathrm{mTSI}_{\mathrm{CR}}$ & D & $J$ & $\mathrm{H}$ & $\mathrm{mTSI}_{\mathrm{ROT}}$ & $\mathrm{mTSI}_{\mathrm{CR}}$ & D & $J$ & $\mathrm{H}$ \\
\hline Depth (cm) & 0.053 & -0.162 & $-.663^{\star \star}$ & 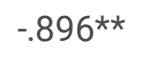 & -0.245 & 0.222 & 0.086 & -0.115 & $-.354^{\star}$ & -0.2 \\
\hline $\mathrm{SD}(\mathrm{cm})$ & -0.021 & 0.221 & 0.005 & -0.23 & 0.022 & 0.161 & 0.001 & -0.337 & $-.604 * \star$ & $-.427 *$ \\
\hline Temp $\left({ }^{0} \mathrm{C}\right)$ & -0.221 & $-.599 \star \star$ & $.388 *$ & $-.382^{\star}$ & 0.186 & 0.004 & -0.301 & 0.001 & $-.544^{\star \star}$ & -0.2 \\
\hline $\mathrm{pH}$ & 0.291 & 0.049 & $.622 * \star$ & -0.11 & $.759 * *$ & -0.024 & -0.069 & 0.051 & -0.2 & 0.02 \\
\hline $\mathrm{EC}(\mu \mathrm{S} / \mathrm{cm})$ & -0.137 & -0.294 & $-.440 *$ & $.590 * \star$ & -0.301 & 0.282 & 0.22 & -0.281 & -0.1 & -0.2 \\
\hline $\mathrm{DO}(\mathrm{mg} / \mathrm{L})$ & $-.471^{\star}$ & $-.532^{\star \star}$ & $.684^{\star \star}$ & $-.534^{\star \star}$ & $.365^{\star}$ & -0.057 & 0.103 & 0.295 & $.531 \star \star$ & $.379 *$ \\
\hline Alk (mg/L) & 0.136 & 0.039 & -0.246 & $.578 * \star$ & 0.022 & -0.094 & $0.394^{*}$ & -0.262 & 0.25 & -0.1 \\
\hline Hard (mg/L) & 0.071 & 0.27 & -0.302 & $.641^{\star \star}$ & 0.079 & 0 & 0.620 ** & -0.244 & $.446^{\star}$ & -0.1 \\
\hline $\mathrm{NO}_{3}{ }^{-} \mathrm{N}(\mathrm{mg} / \mathrm{L})$ & 0.326 & -0.207 & -0.013 & 0.21 & 0.284 & $-.405^{\star}$ & $-0.415^{\star}$ & $.366^{\star}$ & 0.03 & $.388 *$ \\
\hline $\begin{array}{l}\mathrm{PO}_{4}^{-} \mathrm{P} \\
(\mathrm{mg} / \mathrm{L})\end{array}$ & $0.275^{\star}$ & $.613^{\star *}$ & -0.101 & -0.06 & -0.028 & $.495^{\star \star}$ & $.0424^{\star}$ & -0.339 & $-.464^{\star}$ & $-.448^{\star}$ \\
\hline $\mathrm{N}: \mathrm{P}$ & -0.193 & $-.456^{\star}$ & -0.126 & 0.15 & -0.09 & $-.462^{\star}$ & $-.577 \star \star$ & 0.292 & 0.04 & 0.32 \\
\hline $\mathrm{Chl}$ a $(\mu \mathrm{g} / \mathrm{L})$ & $.656^{\star \star}$ & $.468 *$ & 0.002 & 0.29 & 0.226 & $.573^{\star \star}$ & $.414^{\star}$ & $-.434^{\star}$ & $-.479 * *$ & $-.485^{\star x}$ \\
\hline
\end{tabular}


Table 5

The overview of selected trophic status indices methods used in various parts of world for the assessment ecological status of lakes

\begin{tabular}{|c|c|c|c|c|c|}
\hline Country & Aquatic ecosystem type & $\begin{array}{l}\text { Frequency } \\
\text { of } \\
\text { sampling }\end{array}$ & $\begin{array}{l}\text { Period of } \\
\text { sampling }\end{array}$ & $\begin{array}{l}\text { Taxon- and trait-based } \\
\text { trophic indices }\end{array}$ & Reference \\
\hline $\begin{array}{l}\text { North } \\
\text { Eastern } \\
\text { Poland }\end{array}$ & $\begin{array}{l}41 \text { dimictic and } 33 \\
\text { polymictic lakes }\end{array}$ & $\begin{array}{l}\text { Once a } \\
\text { year, during } \\
\text { the summer } \\
\text { stagnation } \\
\text { period }\end{array}$ & 1976- 2005 & $\begin{array}{l}\text { Rotifer based Trophic status } \\
\text { indices (TSI } \mathrm{ROT} \text { ) }\end{array}$ & $\begin{array}{l}\text { EJSMONT- } \\
\text { KARABIN, } 2012\end{array}$ \\
\hline Poland & $\begin{array}{l}12 \text { lakes within Suwałki } \\
\text { Landscape Park }\end{array}$ & Once & $\begin{array}{l}23-31 \text { July } \\
2009\end{array}$ & $\begin{array}{l}\mathrm{TSI}_{\mathrm{SD}}, \mathrm{TSI}_{\mathrm{Chl}}, \mathrm{TSI}_{\mathrm{TP}} \\
\text { Rotifer trophic state indices } \\
\left(\mathrm{TSI} \mathrm{ROT}_{\mathrm{T}}\right) \text { Crustacea trophic } \\
\text { state index }\left(\mathrm{TSI}_{\mathrm{CRU}}\right)\end{array}$ & $\begin{array}{l}\text { Jekatierynczuk } \\
\text { Rudczyk et al., } \\
2014\end{array}$ \\
\hline $\begin{array}{l}\text { Eastern } \\
\text { Poland }\end{array}$ & $\begin{array}{l}\text { Jeziorak, a postglacial } \\
\text { lake }\end{array}$ & Summer & $2011-12$ & $\begin{array}{l}\mathrm{TSI}_{\mathrm{ROT}} \\
\mathrm{TSI}_{\mathrm{TP}+\mathrm{SD}+\mathrm{Chla}}\end{array}$ & $\begin{array}{l}\text { Dembowska et } \\
\text { al., } 2015\end{array}$ \\
\hline India & $\begin{array}{l}\text { OSMANSAGAR } \\
\text { RESERVOIR }\end{array}$ & Monthly & $\begin{array}{l}\text { December } \\
2010 \text { to } \\
\text { November } \\
2012\end{array}$ & $\begin{array}{l}\text { Based on presence of } \\
\text { specific indicator rotifer } \\
\text { species }\end{array}$ & $\begin{array}{l}\text { Karuthapandi } \\
\text { et al., } 2015\end{array}$ \\
\hline Poland & $\begin{array}{l}\text { Suwalki Landscape Park } \\
\text { Typical deep channel } \\
\text { lakes, moraine lakes and } \\
\text { shallow polymictic lakes. }\end{array}$ & Once a year & $\begin{array}{l}\text { July/August } \\
\text { 1983-1985, } \\
2009,2012 \\
\text { and } 2015\end{array}$ & $\begin{array}{l}\text { Rotifer trophic state indices } \\
\left(\mathrm{TSI}_{\mathrm{ROT}}\right)\end{array}$ & $\begin{array}{l}\text { Ejsmont- } \\
\text { Karabin et al., } \\
2016\end{array}$ \\
\hline China & 2 Shallow lakes & $\begin{array}{l}\text { Twice a } \\
\text { month }\end{array}$ & $\begin{array}{l}\text { July } 2012 \text { to } \\
\text { June } 2013\end{array}$ & $\begin{array}{l}\text { Comprehensive trophic state } \\
\text { index (TSI) based on Chl a, } \\
\text { SD (Secchi disk), TN (total } \\
\text { nitrogen) and TP (total } \\
\text { phosphorous) } \\
\text { Tait-based indices: rotifer } \\
\text { community } \\
\text { Guild ratio }\end{array}$ & $\begin{array}{l}\text { Wen et al., } \\
2017\end{array}$ \\
\hline Algeria & $\begin{array}{l}\text { Three reservoirs: } \\
\text { SidiYacoub, Bakhadda, } \\
\text { HammamBoughrara }\end{array}$ & & $\begin{array}{l}\text { December } \\
2015 \text { to } \\
\text { November } \\
2017\end{array}$ & Carlson index and $\mathrm{TSI}_{\mathrm{ROT}}$ & $\begin{array}{l}\text { Smaoune et al. } \\
2020\end{array}$ \\
\hline China & $\begin{array}{l}\text { Han river downstream } \\
\text { (HD), Reservoir (RE) and } \\
\text { Tidal creek (TC) }\end{array}$ & Seasonal & $\begin{array}{l}\text { July } 2015, \\
\text { November } \\
2015, \\
\text { January } 2016 \\
\text { and May } \\
2016\end{array}$ & $\begin{array}{l}\text { Rotifer abundance and the } \\
\text { rotifer trophic state }\end{array}$ & $\begin{array}{l}\text { Liang et al., } \\
2019\end{array}$ \\
\hline
\end{tabular}

CCA was carried out to identify the important environmental factors influencing the zooplankton abundance in Khalsi and Akhaipur lake. The first axis of the CCA (CCA1) explained $23 \%$ of the total variation of the model and $15 \%$ of the variability was explained by the second component. The first two component CCA indicated that the environmental parameters including phosphate, Secchi disk depth (transparency), alkalinity, hardness, electrical conductivity, chlorophyll a and water depth are the important parameters influencing the zooplankton abundance in Khalsi lake. On the other hand nitrate, temperature, $\mathrm{pH}, \mathrm{N}: \mathrm{P}$ and $\mathrm{DO}$ are the important parameters influencing the zooplankton abundance in Akhaipur lake. CCA also indicated that the assemblage pattern of zooplankton in Akhaipur lake was distinct from Khalsi lake (Fig. 5). 


\section{Discussion}

The ecological state of water quality is highly variable in shallow lakes which are disconnected from river, exclusively depend on physico-water quality parameters. The studied both oxbow lakes were significantly different based on electrical conductivity, phosphorus concentration, $\mathrm{DO}, \mathrm{pH}$, alkalinity and hardness. Differences in hydrological parameters may be attributed to riverine connectivity of lakes (Amoros and Bornette, 2002) and other climatological factors( Sarkar et al 2020). Seasonal fluctuation of water depth was significant different due to rainfall of the region and latitudinal connectivity of river channel. Temperature is one of the influencing factors of chemical and biological process of ecosystem (Cremona et al., 2021), fluctuations in temperature were related to regional climatic conditions and air temperature. The $\mathrm{pH}$ value in both the lakes were recorded towards alkaline side with limited fluctuation indicating optimum level BIS (2003) for productivity. The $\mathrm{pH}$ is a vital component for biochemical function of aquatic ecosystem (Jena et al., 2013). Slightly higher pH value in Akaipur lake is influenced by oscillation of metabolic activity of aquatic organism, and photosynthetic activity (Saha et al., 2021)). The coverage of macrophytes in lakes also attributed to diurnal fluctuation in pH value (Rameshkumar et al., 2019). Comparatively lower $\mathrm{pH}$ value in Khalsi might be due to decomposition of macrophyte which is in corollary to the study of Tang et al. (2019). Bala and Mukherjee (2010) observed similar finding in Nadia wetlands of West Bengal. Dissolved oxygen (DO) is one of the health indicators of aquatic ecosystem. DO of both lakes were well within acceptable range (above $5 \mathrm{mg} / \mathrm{L}$ ) for ecological wellbeing. Although DO fluctuation is varying everyday depends on temperature (Ouhmidou et al., 2015). DO concentration in both the lakes was lowest in monsoon and highest in winter season. In lower temperature solubility of oxygen in water increases and photosynthetic activity of aquatic plants is also increases (Hasler et al., 2009; Pedersen et al. 2013). Hardness and alkalinity are comparatively higher in Khalsi, considered as one of the important parameters for secondary productivity (Raju et al. 2014).

$\mathrm{Chl}$ a is one of the most important components to assess overall algal biomass of lakes and classifying to their trophic level (Gregor and Mar`salek 2004). Chl a was comparatively very high in pre-monsoon (PRM) in both the lakes due to decreased water depth of lakes. Annual average Chl a was higher in 2015-16, may be indication towards the eutrophication of lakes. Enclosure culture (pen culture) practice in 2015-16 in both the lakes might have produced higher $\mathrm{PO}_{4}{ }^{-} \mathrm{P}$, which can lead to increasing eutrophication, similarly observed in Baiyangdian lake by Wang et al. (2013). Although, nutrient concentration $\left(\mathrm{NO}_{3}{ }^{-} \mathrm{N}\right.$ and $\left.\mathrm{PO}_{4}{ }^{-} \mathrm{P}\right)$ was increased from 2014-15 to 2015-16 in both the lakes, however, a slight higher increased deviation was reported in Akaipur as compared to the Khalsi. The enhanced organic nutrients particularly, $\mathrm{NO}_{3}{ }^{-} \mathrm{N}$ and $\mathrm{PO}_{4}{ }^{-} \mathrm{P}$ due to unscientific pen culture practices in Akaipur in relation to the total water spread area of the lake as compared to the Khalsi during 2015-2016 that was coinciding the results of (Beveridge, 1984). The highest concentration of $\mathrm{NO3}^{-} \mathrm{N}$ during monsoon (June to September) in the present study may be also due to the allochthonous organic input and the decomposition of the aquatic macrophytes and jute retting (Ghosh and Biswas, 2018). Nutrient $\left(\mathrm{NO}_{3}{ }^{-} \mathrm{N}\right.$ and $\left.\mathrm{PO}_{4}{ }^{-} \mathrm{P}\right)$ concentration was expected reason for accelerating particularly, during second year of studies, indicating transition from high mesotrophic to slight eutrophic. N:P value have decreased significantly in 2015-16 in both the lakes might be both nutrients $\mathrm{NO}^{-} \mathrm{N}^{-1}$ and $\mathrm{PO}_{4}{ }^{-} \mathrm{P}$ have equally contributed towards eutrophication. Tang et al. (2019) suggested $\mathrm{N}$ as to be only limiting factor in Baiyangdian lake and McCarthy et al. (2007) P as limiting factor in Taihu lake, China for eutrophication. The deviation of the result in our study in contrast to this study might be due to the fact that supply of both nitrogen and phosphorus from atmosphere deposition, non-point source as agriculture runoff is potentially a significant source of increasing nutrients loads in lakes.

The pattern of zooplankton community structure and abundance are very important for the maintenance of the ecological health of the aquatic ecosystem. Zooplanktons are considered to be the ecological indicators of aquatic environment (Neto et al. 2014). Rotifers respond quickly to aquatic environmental changes due to their short life cycle and are therefore used as indicators of overall health or condition (Carriack and Schelskek, 1977). Three common species Filinia longispina, Brachionus fulcatus, Keratella cochlearis of rotifer was recorded throughout the study period. Sharma et al. (1992) noted Filinia longispina is as eurytopic alkaline species. Two commonly occurring species Brachionus fulcatus, Keratella cochlearis are of the genus Brachionus and Keratella, considered as cosmopolitans and eurytopic species (Branco et al.

Page $15 / 27$ 
2002; Kumari et al., 2017) due its broader ecological value, thermal tolerance and geographical distribution (Bennett et al., 2019). Rotifer species Filinia longispina, Brachionus rubens, B. fulcatus, B. forficula, Keratella cochlearis, K. tropica, Bosmina longirostris and Polyarthra vulgaris were present in both the lakes with varying degree of abundance. Keratella cochlearis and $K$. tropica have been recorded from many freshwater bodies such as ponds to reservoir (Doukhandji and Arab, 2017). The seven species of rotifers of both lakes have wide range of pollution tolerance (Sládeček 1983; Sharma et al. 1992, Branco et al. 2002; Kumari et al., 2017). Genus Keratella and Brachionus is considered as indication of eutrophic state of the lake due to their close association with nutrient rich surrounding environment, have been confirmed by many authors (Branco et al., 2002; Kumari et al., 2017; Doukhandji and Arab, 2017; Smaoune et al., 2020). Genus Polyarthra was less abundant in both the lakes due to high nutrient availability, less tolerance and other environmental factors. García-Chicote et al. (2018) was reported as indicator of mesotrophic state, while other available reports say the occurrence of Polyarthra in both oligitrophic and eutrophic lakes ( Obertegger et al., 2008; Obertegger et al., 2014; Karpowicz et al., 2020). In the present study, in winter (higher $\mathrm{PO}^{-} \mathrm{P}$ ), Polyarthra were absent, therefore this genus is indicator of oligrophic to mesotrophic state. Genus Trichocerca was recorded only in post monsoon and winter, when nutrient concentration was higher. Castro et al. (2005) was also reported the genus from eutrophic environment and agreed with our finding. Genus Bosmina was relatively abundant in throughout the seasons except in monsoon. In monsoon season, generally flow of water is higher compare to other seasons and Cladocerans usually prefer lentic water (littoral zone with macrophytes) than lotic water (Maia-Barbosa et al. 2008; Jeong et al (2015), therefore the genera was absent in both lakes in monsoon. Only cladocerans Ceriodaphnia cornuta, Moina branchiate and M. micrura were recorded during monsoon seasons in Khalsi because of their preference towards clear water and macrophyte dominant reasons. Mergeay et al (2006) have also found similar result and confirm their association in macrophyte dominated reasons in shallow Kenyan lakes lakes of southern Kenya. More abundance of copepods in monsoon and post-mansoon indicated well mixing of nutrients and favorable temperature. Yin et al. (2018) also reported higher abundance of copepod in mesotrophic lake. Copepod adult have greater preference towards higher nutrient rich environment than naupli. Mathews et al. (2018) have reported that favorable temperature range $25-28^{\circ} \mathrm{C}$ for copepod growth and reproduction copepod. In this context monsoon and post-mosoon season is most favorable season for higher abundance of copepods. Ostracod communities have close association with aquatic macrophytes (Matsuda et al., 2015) and higher ecological tolerance (Kiss, 2007). Centropyxis, Diffulgia and Arcella were dominant in Khalsi but Centropyxis in Akaipur, throughout the study period, all these protozoans are having wide range of tolerance of nutrients, found in oligotrophic to eutrophic conditions (Madoni 2011).

Measuring zooplankton Species diversity is one of the most important characteristics of aquatic ecosystem to maintain stability as means of coping with any environmental changes. We have compared the value of various indices between two lakes. We have found that lowest diversity indices $\mathrm{H}^{\prime}$ and $\mathrm{D}$ from Akaipur during winter. Diversity have been decreased due to unscientific enclosure culture practice and lack of connectivity with main river channnel that might have corroborated factors such abiotic factor, natural predation by copepod and cladoceran, competition for food and increasing eutrophication (Marcus, 2004; Perbiche-Neves et al., 2016; Arcifa et al., 2020).

The $\mathrm{mTSI}_{\mathrm{ROT}}$ and $\mathrm{mTSI}_{\mathrm{CR}}$ values were determined annually for both the lakes but spatial as well as temporal difference was insignificant. Rotifer community among the zooplankton shows quick response to the environmental changes, is considered as highly suitable foe assessing degree of eutrophication, have been confirmed by many authors (Jekatierynczuk-Rudczyk et al., 2014; Dembowska et al., 2015; Ejsmont-Karabin et al., 2016; Wen et al., 2017; Smaoune et al., 2020). In this study trophic state index was assessed based on rotifer and crustacean groups. The $\mathrm{mTSI} \mathrm{ROT}_{\mathrm{T}}$ and $\mathrm{mTSI}_{\mathrm{CR}}$ found positively significantly relationship with phosphorus concentration $\left(\mathrm{PO}_{4}{ }^{-} \mathrm{P}\right)$ in both the lakes. Similar finding was reported by Xiong et al. (2016) from two subtropical lakes. Although, there are cumulative effect of many abiotic factors in changing the trophic dynamics of ecosystem $\mathrm{PO}_{4}{ }^{-} \mathrm{P}$ and $\mathrm{Chl}$ a showed significantly positive relationship towards eutrophication.

The composition and diversity of zooplankton species with higher trophic state have well explained by combination of environmental parameters with Pearson's correlations and CCA analysis. García-Chicote et al. (2018) explained the 
dominance of some of the species in ecological stressful environment. Our result also shows dominance of genus Brachionus influenced by $\mathrm{NO}_{3}{ }^{-} \mathrm{N}$ rich environment also supported by favourable temp and $\mathrm{pH}$. According to Branco et al. 2002; Kumari et al., 2017 dominance of genus Brachionus is a considerably good indicator of eutrophication of the lakes. Present study also reveals the fluctuation in species composition with high level of eutrophication and agreed by Obertegger and Manca (2011). The density of rotifers much more prevalent in both the lakes

\section{Conclusion}

Based on the scientific evidences, rotifers proved their strong sensitivity of nutrient load in freshwater ecosystem. The present investigation advocate the suitability of rotifers based TSIs which is first of its kind, integrating with physicochemical mTSIs to assume and validate biological indices to suggest an indicator species for determination of water quality and ecosystem health of the lakes. The $\mathrm{MTSI}_{\mathrm{CR}}$ and TSI based combination of environmental factors have revalidated our finding to assess degree of eutrophication of oxbow lakes. The study highlights the importance of understanding riverine connectivity of lakes and short term impact of enclosure culture on degree of eutrophication of lakes. The present investigation could further help us to understand the phenological mechanisms of water quality and rotifer abundance for scientific management. Nutrient concentration $\mathrm{PO}_{4}{ }^{-} \mathrm{P}$, temperature, $\mathrm{Chl}$ a, EC, Hard, Alk and SD was found to be most significant influencing factor in both lakes. Based on the finding following points can be concluded.

- Khalsi, a partially open wetland has more sinking capacity as compared to Akaipur (closed wetland) that that left a marginal scope for continue enclosure culture practices on long term basis and suggested a holistic investigation on impact assessment.

- Khalsi has more fish production potential and essential water quality parameters for open water fisheries in optimal range emphasizing upon the scientific management and ecosystem based approach for sustainable fish production to the riparian communities.

- Akaipur is required immediate intervention in terms of restricted irrational culture practices and to cutoff point source of organic load as per the sinking capacity of the wetland.

- Akaipur might be succeeding toward super eutrophication if same practices continue for long term without considering scientific management.

- Present study is first of its kind to validate the physico-chemical and biotic factors with rotifer and crustacean based indices thus advocating that rotifers can be considered as excellent indicator organism for ecological assessment, water quality monitoring and assessment of degree of eutrophication for better policy decisions.

- Thus, addressing the issues related to the eco-hydrological alteration taking place in the closed and semi-closed lakes for fisheries enhancement and carry forward ecosystem services in sustainable manner for wellbeing of the riparian community.

\section{Declarations}

\section{Acknowledgment}

This work was financially supported by, ICAR-CIFRI Under Institute project. The Author is grateful towards the Director ICARCIFRI for providing necessary facility. The authors also thank Bandana Das Ghosh for their help with map drawing. We would like to thank Mr. Y. Ali and Mr. Bablu Naskar for their assistance in sampling. The authors are also acknowl-edge constructive suggestions of anonymous reviewers and constructive comments which helped us in strengthening the manuscript.

\section{Authors Contributions:}


Conceptualization: Uttam Kumar Sarkar, Suman Kumari and Ashok Kumar Jaiswar, Formal analysis and data collection: Lianthuamluaia Lianthuamluaia, Mishal Puthiyottil, Sandhya Kavitha Mandhir, Data collection: Darmendra Kumar Meena, , Data Support: Md. Abul Hassan, Methodology: Suman Kumari and Mishal Pudyottil, Original draft preparation: Suman Kumari, Lianthuamluaia Lianthuamluaia, Review and editing: Gunjan Karnatak, Uttam Kumar Sarkar, Mishal Puthiyottil, Funding acquisition: Anil Prakash Sharma and Basanta Kumar Das, All the au-thors read and approved the final manuscript.

\section{Funding}

The research was conducted with the fund support of the ICAR-Central Inland Fisheries Research Institute.

\section{Data availability}

Data will be available based on request.

\section{Ethics approval}

The submitted manuscript is not submitted in any other journal.

Consent to participate: Not applicable

\section{Consent for publication}

The approval for submitting the manuscript was received from the ICAR-Central Inland Fisheries Research Institute.

\section{Competing interests}

The authors declare no competing interests.

\section{Disclaimer}

The statements made herein are solely the responsibil-ity of the authors

\section{References}

1. Abell JM, van Dam-Bates P, Özkundakci O, Hamilton DP (2020) Reference and current trophic level index of New Zealand lakes: benchmarks to inform lake management and assessment. N Z J Mar Freshwat Res 54:636-657. doi: 10.1080/00288330.2020.1726974

2. Adamovich BV, Zhukova TV, Mikheeva TM et al (2016) Long-term variations of the trophic state index in the Narochanskie Lakes and its relation with the major hydroecological parameters. Water Resour 43:809-817. https://doi.org/10.1134/S009780781605002X

3. American Public Health Association (2005) Standard methods for the examination of water and wastewater. 21st ed. Washington, DC. pp 870

4. Amoros C, Bornette G (2002) Connectivity and biocomplexity in waterbodies of riverine floodplains. Freshwater Biology (2002) 47, 761-776

5. Arcifa MS, de Souza BB, de MoraisJunior CS, Bruno CCC (2020) Functional groups of rotifers and an exotic species in a tropical shallow lake. Sci Rep 10:14698. https://doi.org/10.1038/s41598-020-71778-1

6. Bala G, Mukherjee A (2010) Water quality index of some wetland in Nadia district, West Bengal, India. Int J Lake Rivers 4(1):21-26

7. Battish SK (1992) Freshwater Zooplankton of India. Oxford and IBH Publishing Co., New Delhi, p 233

8. Bennett S, Duarte CM, Marbà N, Wernberg T (2019) Integrating within-species variation in thermal physiology into climate change ecology. Philos Trans R Soc Lond B Biol Sci 374(1778):20180550. doi:10.1098/rstb.2018.0550 
9. Benzie JAH (2005) The genus Daphnia (including Daphniopsis) (Anomopoda: Daphniidae). In: Dumont HJ (ed) Guides to the Identification of the Microinvertebrates of the Continental Waters of the World 21. Ghent \& Backhuys Publishers, Leiden, Kenobi Productions

10. Beveridge MCM (1984) Cage and pen fish farming. Carrying capacity models and environmental impact.FAO Fish Tech Pap(255):131p

11. Biswas BC, Panigrahi AK (2015) Ecology and zooplankton diversity of a wetland of jhenidah district, Bangladesh. Int J Innov Res Sci Eng Technol 1(9):246-249

12. Bottrell HH, Duncan A, Gliwicz ZM, Grygierek EA, Herzig H, Kurasawa H, Larsson P, Weglenska T (1976) A review of some problems in zooplankton production studies. Norw J Zool 24:419-456

13. Branco CWC, Roch MIA, Pinto GFS, Gomara GA, Filippo R (2002) Limnological features of ^ Funil Reservoir (R.J., Brazil) and indicator properties of rotifers and cladocerans of the zooplankton community. Lakes Reserv Res Manag 7:87-92. 10.1046/j.1440- 169X.2002.00177.x

14. Carlson RE (1977) A Trophic State Index for Lakes. Limnol Oceanogr 22(2):361-369

15. Carlson RE, Havens KE (2005) Graphical methods for the interpretation of relationships between trophic state variables. Lake and Reserv Manage 21(1):107-118

16. Carriack JH, Schelske LC (1977) Have we over looked the importance of small phytoplankton in productive waters. Limnol Oceanog 42:1612-1613

17. Castro BB, Antunes SC, Pereira R, Soares AMVM, Gonçalves F (2005) Rotifer community structure in three shallow lakes: seasonal fluctuations and explanatory factors. Hydrobiologia 543:221-232

18. Chaudhuri SR, Mishra M, Salodkar S, Sudarshan M, Thakur AR (2008) Traditional aquaculture practice at east Calcutta Wetland: The safety assessment. Am J Environ Sci 4:140-144. DOI: 10.3844/ajessp.2008.140.144

19. Cremona F, Blank K, Haberman J (2021) Effects of environmental stressors and their interactions on zooplankton biomass and abundance in a large eutrophic lake. Hydrobiologia (2021) 848:4401-4418.

https://doi.org/10.1007/s10750-021-04653-3

20. Das BK, Roy A, Som S, Chandra G, Kumari S, Sarkar UK, Bhattacharjya BK, Das AK, Pandit A (2021) Impact of COVID-19 lockdown on small-scale fishers (SSF) engaged in floodplain wetland fisheries: evidences from three states in India. Environ Sci Pollut Res (2021). https://doi.org/10.1007/s11356-021-16074-9

21. Dembowska E, Napiórkowski P, Mieszczankin T, Józefowicz S (2015) Planktonic indices in the evaluation of the ecological status and the trophic state of the longest lake in Poland. Ecol Ind 56:15-22. https://doi.org/10.1016/j.ecolind.2015.03.019

22. Doukhandji N, Arab A (2017) The spatio-temporal distribution of Rotifers in a dam in a Saharan climate region (Foum El Gherza, Algeria). Revue d'écologie 72(2):168-176. http://hdl.handle.net/2042/62077

23. Dussart B, Defaye D (2001) Introduction to Copepods, 2nd edn. Backhuys Publishers, Leiden

24. Edmondson WT (1959) Rotifers. In: Edmondson WT (ed) Fresh-water Biology, 2nd edn. Wiley, New York, pp 1248, pp 420-494

25. Ejsmont-Karabin J (2012) The usefulness of zooplankton as lake ecosystem indicators: rotifer trophic index. Pol J Ecol 60:339-350

26. Ejsmont-Karabin J, Karabin A (2013) The suitability of zooplankton as lake ecosystem indicators: crustacean trophic state index. Polish J Ecology 61:561-573

27. Ejsmont-Karabin J, Górniak A, Maciej Karpowicz M (2016) Diversity of rotifer communities in lakes of the Suwalki Landscape Park. Limnol Rev 16:4: 207-211. DOI 10.1515/limre-2016-0022

28. Araújo FG, de Azevedo MCC, Ferreira MDNL (2011) Seasonal changes and spatial variation in the water quality of a eutrophic tropical reservoir determined by the inflowing river. Lake Reserv Manag 27(4):343-354. DOI:

$10.1080 / 07438141.2011 .627753$

Page 19/27 
29. Ganesan L, Khan RA (2008) Studies on the Ecology of Zooplankton in a Oxbow Wetland of West Bengal, India. In Sengupta, M. and R. Dalwani (Eds) Proceedings of Taal 2007: The 12th World Lake Conference, pp 67-73

30. García-Chicote J, Armengol X, Rojo C (2018) Zooplankton abundance: a neglected key element in the evaluation of reservoir water quality. Limnologica 69:46-54

31. Ghosh D, Biswas JK (2015) Impact of jute retting on native fish diversity and aquatic health of roadside transitory water bodies: an assessment in Eastern India. J Ecolog Engine 16(4):14-21. DOI: 10.12911/22998993/59342

32. Ghosh D, Biswas JK (2018) Impact of jute retting on physicochemical profile of Chhariganga oxbow lake in Nadia district, West Bengal, India. Archives of Agriculture and Environmental Science 3(1):36-44. DOI:

$10.26832 / 24566632.2018 .030104$

33. Gregor J, Mar`salek ' B (2004) Freshwater phytoplankton quantification by chlorophyll a: A comparative study of in vitro, in vivo and in situ methods. Water Res 38:517-522. https://doi.org/10.1016/j.watres.2003.10.033

34. Hasler N, Werth D, Avissar R (2009) Effects of tropical deforestation on global hydroclimate: a multimodel ensemble analysis. J Clim 22:1124-1141

35. Janseen ABG, Teurlines S, An S, Janse JH, Paerl HW, Mooij WM (2014) Alternative stable states in large shallow lakes? J Great Lakes Res 40:813-826

36. Jekatierynczuk-Rudczyk E, Zieliński P, Grabowska M et al (2014) The trophic status of Suwałki Landscape Park lakes based on selected parameters (NE Poland). Environ Monit Assess 186:5101-5121. https://doi.org/10.1007/s10661014-3763-0

37. Jena V, Dixit S, Gupta S (2013) Assessment of water quality index of industrial area surface water samples. Int J Chem Res 5(1):278-283

38. Jeong H, Kotov AA, Lee W, Jeong R, Cheon S (2015) Diversity of freshwater Cladoceran species (Crustacea: Branchiopoda) in South Korea. J Ecol Environ 38(3):361-366

39. Junk WJ, Piedade MTF, Lourival R, Wittmann F, Kandus P, Lacerda LD, Bozelli RL, Esteves FA, Cunha CN, Maltchik L et al (2014) Brazilian lakes: their definition, delineation, and classification for research, sustainable management, and protection. Aquatic Conservation: Mar Freshw Ecosys 24:5-22

40. Sandhya KM, Roy A, Hassan MA, Kumari S, Mishal P, Kumar LiamthuanluaiaL, Aftabuddin V, Bhattacharjya M, Meena BK, Ali DK, Naskar Y B (2019) Traditional Fishing Gears, Fish Catch and Species Composition of Selected Floodplain Wetlands of Lower Gangetic Plains, West Bengal, India. Fish Technol 56:101-109

41. Karnatak G, Sarkar U, Naskar M et al (2020) Modeling pre-spawning fitness and optimal climate of spotted snakehead Channa punctata (Bloch, 1793) from a Gangetic floodplain wetland of West Bengal, India. Int J Biometeorol 64, 18891898 (2020). https://doi.org/10.1007/s00484-020-01976-z

42. Karpowicz M, Ejsmont-Karabin J, Kozłowska J, Feniova I, Dzialowski AR (2020) Zooplankton Community Responses to Oxygen Stress. Water 12:706. 10.3390/w12030706. doi

43. Kiss A (2007) Factors affecting spatial a temporal distribution of Ostracoda assemblages in different macrophyte habitats os a shallow lake (Lake Fehér, Hungary). Hydrobiologia 585:89-98

44. Koste W (1978) Rotatoria. Die Radertiere Mitteleuropas. UberordnungMonogononta. Ein Bestimmungswerk, begrundet von Max Voigt. 2. Auflage neubearbeitet von Walter Koste. 2 Bande. Textband: VIII, 673 S., ISBN 3-443-39071-4 II Tafelband: Il, 476 S., 234 Taf

45. Kotov A, Forró L, Korovchinsky N, Petrusek A (2013) World checklist of freshwater Cladocera species, World Wide Web electronic publication. Available online at http://fada.biodiversity.be/group/show/17

46. Kumari S, Hassan MA, Lianthuamluaia, Sandhya KM, Mishal P, Kumar V, Sarkar UK, Jaiswar AK, Deshmukhe G, Shenoy $L$ (2017) Influence of environmental factors on rotifer abundance and biomass in a shallow, tropical oxbow lake, west Bengal. The Bioscan 11(2):129-135 
47. Lehette P, Hernández-León S (2009) Zooplankton biomass estimation from digitized images: a comparison between subtropical and Antarctic organisms. Assoc Sci Limnol Oceanogr Methods 7:304-308

48. Liang Z, Soranno PA, Wagner T (2020) The role of phosphorus and nitrogen on chlorophyll a: Evidence from hundreds of lakes, Water Research, 185, 2020,116236,ISSN 0043-1354,https://doi.org/10.1016/j.watres.2020.116236

49. Madoni P (2011) Protozoa in wastewater treatment processes: A minireview. Italian J Zool 78(1):3-11. DOI: $10.1080 / 11250000903373797$

50. Maia-Barbosa PM, Peixoto RS, Guimaraes AS (2008) Zooplankton in littoral waters of a tropical lake: a revisited biodiversity. Braz J Biol 68:1069-1078

51. Marcus N (2004) An overview of the impacts of eutrophication and chemical pollutants on copepods of the coastal zone. Zool Stud 43:211-217

52. Margalef R (1958) Temporal succession and spatial heterogeneity in phytoplankton. In: Perspectives in Marine biology, Buzzati-Traverso (ed.), Univ. Calif. Press, Berkeley pp 323-347

53. Mason CF (1966) Biology of Freshwater Pollution 3rd Edn. Longman Group Ltd,, England, p 356

54. Mathews L, Faithfull CL, Lenz PH, Nelson CE (2018) The effects of food stoichiometry and temperature on copepods are mediated by ontogeny. Oecologia. 2018; 188(1):75-84. doi: 10.1007/s00442-018-4183-6

55. Matsuda JT, Lansac-Tôha FA, Martens K et al (2015) Association of body size and behavior of freshwater ostracods (Crustacea, Ostracoda) with aquatic macrophytes. Aquat Ecol 49:321-331. https://doi.org/10.1007/s10452-015-9527-2

56. McCarthy MJ, Gardner WS, Lehmann MF, Bird DF (2013) Implications of water column 750 ammonium uptake and regeneration for the nitrogen budget in temperate, eutrophic Missisquoi 751 Bay, Lake Champlain (Canada/USA), Hydrobiologia. 718:173-188. 10.1007/s10750- 752 013-1614-6. 1

57. Meena DK, Lianthuamluia L, Mishal P, Swain HS, Naskar BK, Saha S, Sandhya KM, Kumari S, Tayung T, Sarkar UK, Das BK (2019) Assemblage patterns and community structure of macro-zoobenthos and temporal dynamics of ecophysiological indices of two lakes, in lower gangetic plains under varying ecological regimes: A tool for wetland management. Ecol Eng 130:1-20

58. Mergeay J, Declerck S, Verschuren D, De Meester L (2006) Daphnia community analysis in shallow Kenyan lakes and ponds using dormant eggs in surface sediments. Freshwater Biology (2006) 51, 399-411

59. Neto AJG, Silva LC, Saggio AA, Rocha O (2014) Zooplankton communities as eutrophication bioindicators in tropical reservoirs. http://dx.doi.org/10.1590/1676-06032014001814

60. Nogrady T, Segers H, Dumont HJ (eds) (2002) Guides to the Identification of the Microinvertebrates of the Continental Waters of the World 18.Backhuys Publishers BV, Dordrecht, The Netherlands

61. Obertegger U, Flaim G, Sommaruga R (2008) Multifactorial nature of rotifer water layer preferences in an oligotrophic lake. J Plankton Res 30(6):633-643. https://doi.org/10.1093/plankt/fbn027

62. Obertegger U, Flaim G, Fontaneto D (2014) Cryptic diversity within the rotifer Polyarthra dolichoptera along an altitudinal gradient. Freshw Biol 59(11):2413-2427. https://doi.org/10.1111/fwb.12447

63. Obertegger U, Manca M (2011) Response of rotifer functional groups to changing trophic state and crustacean community. J Limnol 70:231-238

64. Oh HJ, Jeong HG, Nam GS, Oda Y, Dai W, Lee EH, Kong D, Hwang SJ, Chang KH (2017) Comparison of taxon-based and trophi-based response patterns of rotifer community to water quality: applicability of the rotifer functional group as an indicator of water quality. Animal Cells and Systems 21(2):133-140. DOI: 10.1080/19768354.2017.1292952. (Wu and Wang /19768354.2017.1292952 To link to this article

65. Ouhmidou M, Chahlaoui A, Kharroubi A, Chahboune M (2015) Study of the physico-chemical and bacteriological quality of the barrage Hassan Addakhil of Errachidia (Morocco). J Mater Environ Sci 6(6):1663-1671

66. Pedersen O, Colmer TD, Sand-Jensen K (2013) Underwater photosynthesis of submerged plants - recent advances and methods. Front. Plant Sci. https://doi.org/10.3389/fpls.2013.00140

Page $21 / 27$ 
67. Perbiche-Neves G, Saito VS, Previattelli D, da Rocha CEF, Nogueira MG (2016) Cyclopoid copepods as bioindicators of eutrophication in reservoirs: Do patterns hold for large spatial extents? Ecol Indic 70:340-347

68. Pielou EC (1966) The measurement of diversity in different types of biological collections. J Theor Biol 13:131-144

69. Raju PARK, Reddy MSR, Raghuram P, Suri Babu G, Rambabu T, Kumar JJ (2014) Alkalinity and Hardness Variation in Ground Waters of East Godavari District due to Aquaculture. IJFAS 1(6):121-127

70. Rameshkumar S, Radhakrishnan K, Aanand S, Rajaram R (2019) Infuence of physicochemical water quality on aquatic macrophyte diversity in seasonal wetlands. Applied Water Science (2019) 9:12 https://doi.org/10.1007/s13201-0180888-2

71. Roshith CM, Meena DK, Manna RK, Sahoo AK, Swain HS, Raman RK, Sengupta A, Das BK (2018) Phytoplankton community structure of the Genetic (Hooghly-Matla) estuary: Status and ecological implications in relation to ecoclimatic variability. Flora 240:133-143

72. Ruttner-Kolisko A (1977) Suggestions for biomass calculation of plankton rotifers. Arch.Hydrobiol-Beih Ergebn Limnol(8):71-76

73. Saha A, Ramya VL, Jesna PK, Sibina Mol S, Panikkar P, Vijaykumar ME, Sarkar UK, Das BK (2021) Evaluation of Spatiotemporal Changes in Surface Water Quality and Their Suitability for Designated Uses, Mettur Reservoir, India. Nat Resour Res 30:2

74. Sandhya KM, Hassan MA, Kumari S, Mishal P, Lianthuamluaia L, Kumar V, Aftabuddin M, Meena DK (2016) Lengthweight relationships of four indigenous freshwater fish species from Khalsi wetland in lower Ganga basin, West Bengal, India. J Appl Ichthyol 32:505-506. DOI:10.1111/jai.13005

75. Sanyal P, Bhattacharya N, Chakraborty S (2015) Biomonitoring of Four Contrasting Wetlands of Kolkata, West Bengal Based on Zooplankton Ecodynamics and Biotic Indices. Journal of Environmental Protection 6:683-699. doi: 10.4236/jep.2015.67062

76. Sarkar S, Sarkar UK, Sajina AM, Kumari S, Mishal P (2021a) Status, ecological services and management of aquatic weeds of floodplain wetlands in India: An overview. Lakes \& Reservoirs Research \& Management. DOI:

$10.1111 /$ Ire. 12353

77. Sarkar UK, Johnson C, Kumari S, Bakshi S, Karnatak G, Ghosh BD, Mishal P, Lianthuamluaia, Das BK (2021) Population dynamics of Indian river shad Gudusia chapra (Hamilton, 1822) using length frequency analysis for fisheries management in a floodplain wetland of Ganga River Basin, India. Lakes and Reservoirs 26(3). https://doi.org/10.1111//re.12365

78. Sarkar UK, Mishal P, Borah S, Karnatak G, Chandra G, Kumari S, Meena DK, Debnath D, Sona Yengkokpam S, Das P, DebRoy P, Yadav AK, Md Aftabuddin, Gogoi P, Pandit A, Bhattacharjya BK, Tayung T, Lianthuamluaia L, Das BK (2020) Status, Potential, Prospects, and Issues of Floodplain Wetland Fisheries in India: Synthesis and Review for Sustainable Management. Reviews in Fisheries Science \& Aquaculture 29(1):1-32. DOI: 10.1080/23308249.2020.1779650

79. Sarkar UK, Roy K, Naskar M, Karnatak G, Mishal P, Baksi S, Kumari S, Lianthuamluia L, Das BK (2021b) Assessing vulnerability of freshwater minnows in the Gangetic floodplains of India for conservation and management: Anthropogenic or climatic change risk? Climate Risk Management 33(2021):100325. https://doi.org/10.1016/j.crm.2021.100325

80. Sarma D, Dutta A (2012) Ecological study of two riverine lakes of goalpara District of Assam. India. Nat Env Pollut Technol 1(2):297-302

81. Schindler DW, Noven B (1971) Vertical distribution and seasonal abundance of zooplankton in two shallow lakes of the Experimental Lakes Area, North western Ontario. J Fish Res Board Can 28:245-256

82. Segers H (1995) Rotifera. Volume 2: The Lecanidae (Monogononta). SPB Academic Publishing, p 226

83. Sehgal KL (1983) Planktonic Copepods of Freshwater Ecosystems. Interprint, New Delhi, p 169

84. Shannon CE, Weaver W (1949) The Mathematical Theory of Communication. University of Illinois Press, Urbana

Page 22/27 
85. Sharma BK, Sharma S, Dunani VK (1992) Freshwater Rotifer from Darbhanga city. Bihar Rec Zool Surv India 91(34):431-448

86. Sharma BK (2009) Diversity of Rotifers (Rotifera: Eurotatoria) of Loktak lake, north-eastern India.Tropical Ecol(50):277285

87. Sharma BK (2011) Zooplankton communities of Deepor Beel (a Ramsar site), Assam (N. E. India): ecology, richness, and abundance. J Trop Ecol 52(3):293-302

88. Sharma BK, Sharma S (2012) Diversity of zooplankton in a tropical Oxbow lake of the Brahmaputra river basin, Assam (Northeast India). Opuscula Zool 43(2):187-195

89. Sharma P, Bora PJ (2020) Water Quality Assessment Using Water Quality Index and Principal Component Analysis: A Case Study of Historically Important Lakes of Guwahati City, North-East India. Applied Ecology and Environmental Sciences. 2020; 8(5):207-217. doi: 10.12691/aees-8-5-4

90. Sládeček V (1983) Rotifers as indicators of water quality. Hydrobiologia 100:169-171

91. Smaoune G, Bouchelouche D, Taleb A et al (2021) Evaluation of the trophic status in three reservoirs in Algeria (north west) using physicochemical analysis and rotifers structure. Environ Sci Pollut Res 28::46627-46642. https://doi.org/10.1007/s11356-020-11233-w

92. Strickland JD, Parson TR (1972) A practical handbook of seawater analysis. Fishery Research Board, Canada, p 310

93. Tang C, Yi Y, Yang Z, Zhang S, Liu H (2018) Effects of ecological flows release pattern on water quality and ecological restoration of a large shallow lakes. J Clean Prod 174:577-590

94. Tang C, Yi Y, Yang Z, Zhou Y, Zerizghi T, Wang X (2019) Planktonic indicator of trophiuc states for a shallow lake (Baiyangdian lake China). Limnologica 78:125712

95. Victor R, Fernando CH (1979) The freshwater Ostracods of India. Rec Zool Surv India Occ Paper 74(1-4):147-242

96. Vörös L, Padisak J (1991) Phytoplankton biomass and chlorophyll $a$ in some shallow lakes in central Europe. Hydrobiologia 215:111-119

97. Walter TC, Boxshall G (2015) Cyclopidae Rafinesque, 1815. World of Copepods database. $x$ details\&id=106413, Available online at. http://www.marinespecies.org/aphia.php?p=ta

98. Wang X, Wang Y, Liu L, Shu J, Zhu Y, Zhou J (2013) Phytoplankton and Eutrophication Degree Assessment of Baiyangdian Lake Wetland, China. Scientific World Journal 25:436965. doi: 10.1155/2013/436965

99. Wen X, Zhai P, Feng R et al (2017) Comparative analysis of the spatio-temporal dynamics of rotifer community structure based on taxonomic indices and functional groups in two subtropical lakes. Sci Rep 7:578.

https://doi.org/10.1038/s41598-017-00666-y

100. Xiong W, Li J, Chen Y, Shan B, Wang W, Zhan A (2016) Determinants of community structure of zooplankton in heavily polluted river ecosystems. Sci Rep 6(1):22043. PMid:26912391 http://dx.doi.org/10.1038/srep22043

\section{Figures}




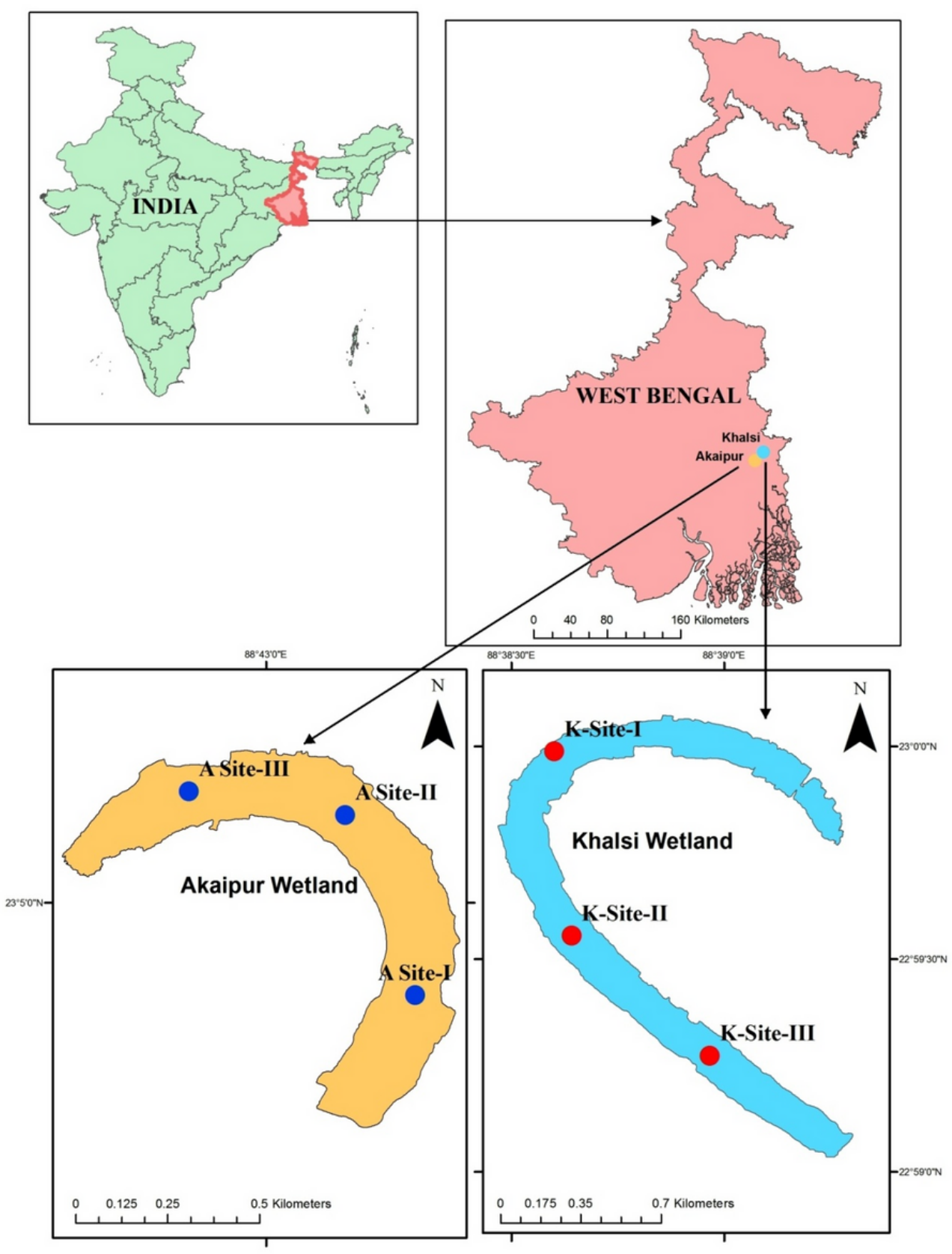

Figure 1

The Khalsi and Akaipur oxbow lakes and their sampling locations 


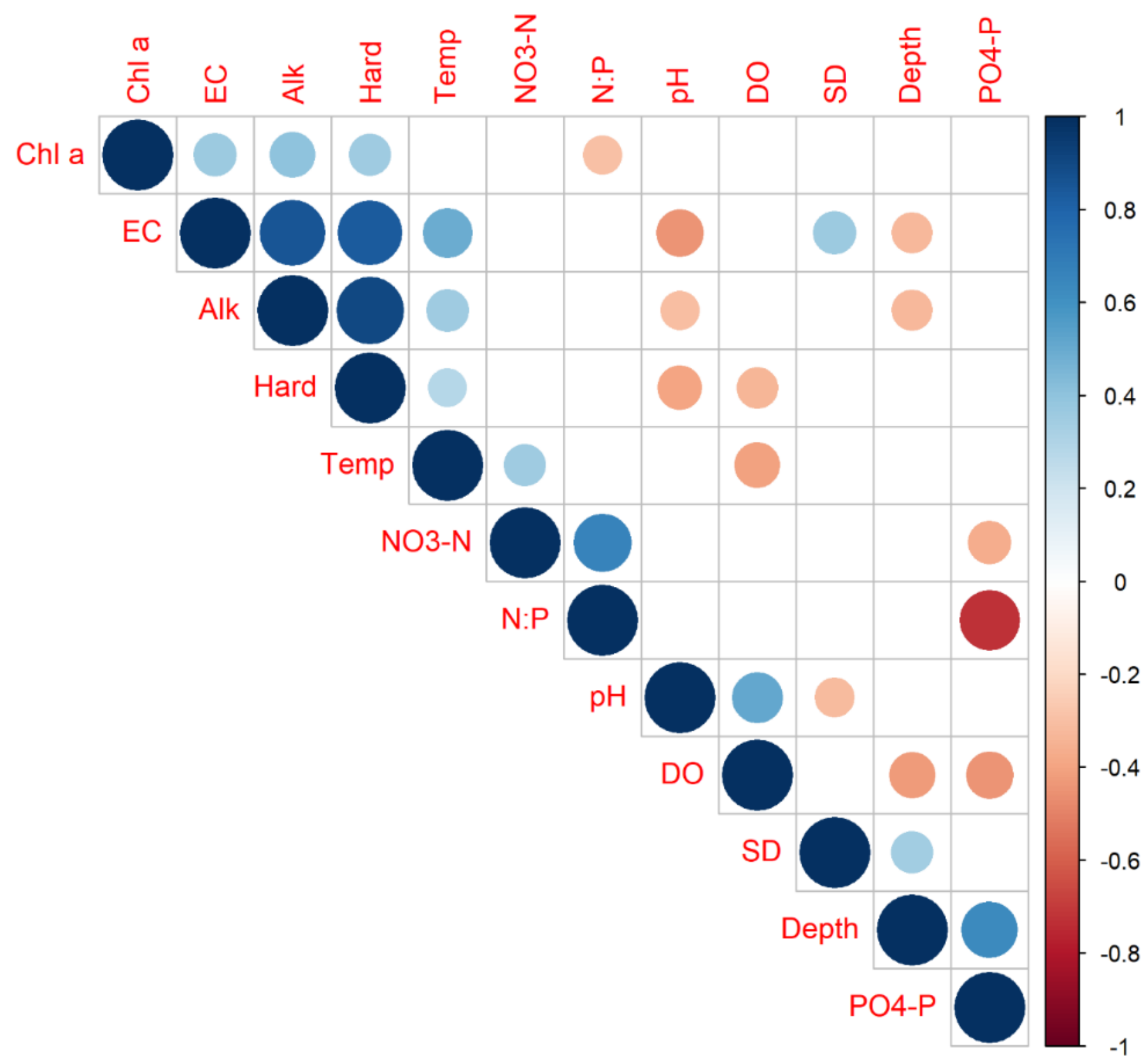

Figure 2

Correlogram of environmental variables of lakes Note: $\mathrm{Chl} \mathrm{a=} \mathrm{Chlorophyll} \mathrm{a;} \mathrm{EC=} \mathrm{electrical} \mathrm{conductance;} \mathrm{Alk=} \mathrm{alkalinity;}$ Hard=hardness; Temp= water temperature; NO3-N= nitrate nitrogen; N/P=nitrate/phosphate; $\mathrm{DO}=$ dissolved oxygen; $\mathrm{SD}=$ Scechi depth;P04-P= phosphate phosphorus; 

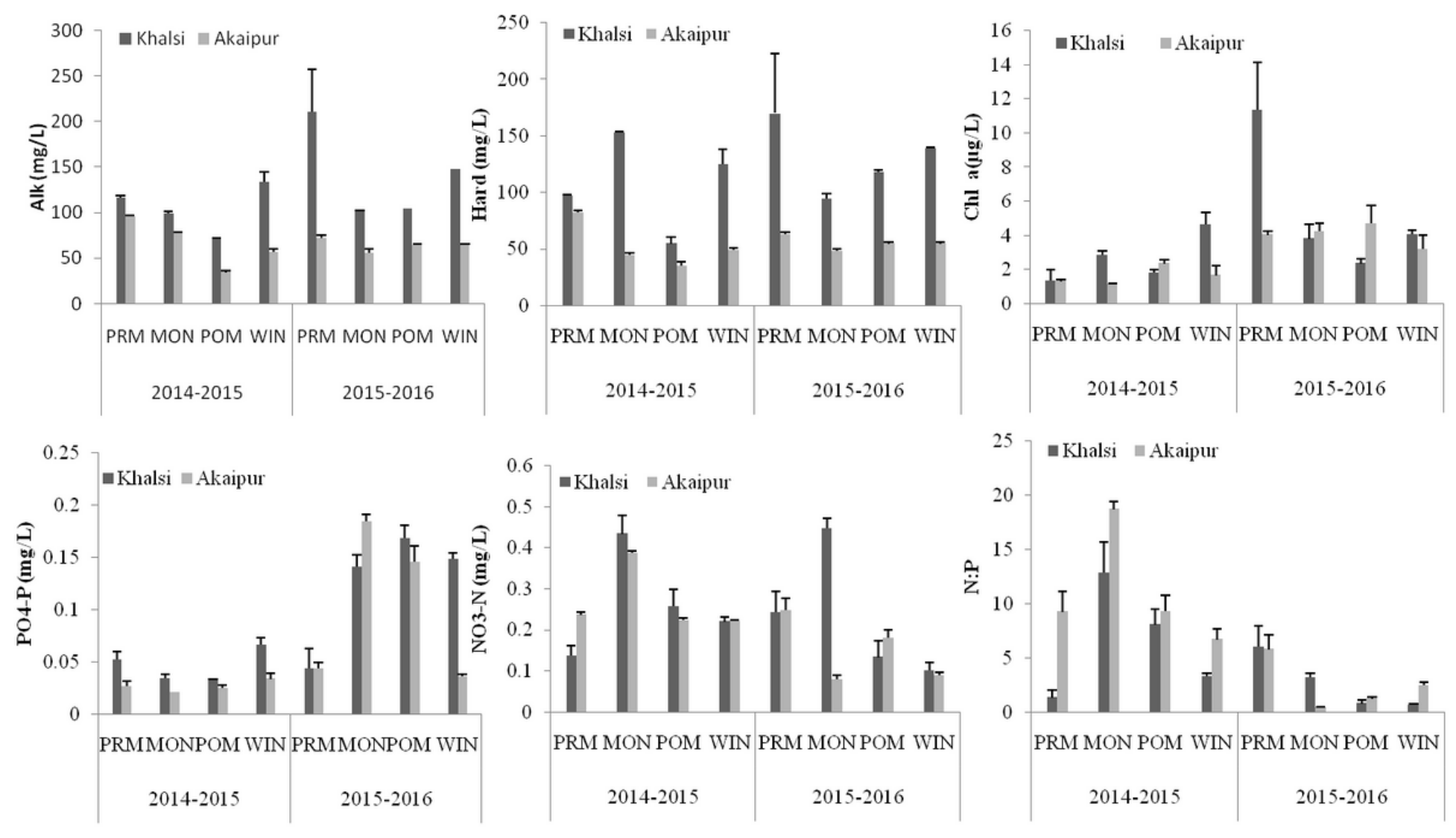

Figure 3

Spatio-temporal variations of environmental parameters viz: Depth, Secchi depth (SD),Water temperature (Temp),pH, Electrical conductivity (EC),Dissolved oxygen (DO), Total Alkalinity (Alk),Total Hardness (Hard), Chlorophyll a (Chl a), Phosphate (PO4-P), Nitrate (NO3-N), Nitrate: phosphate (N:P),
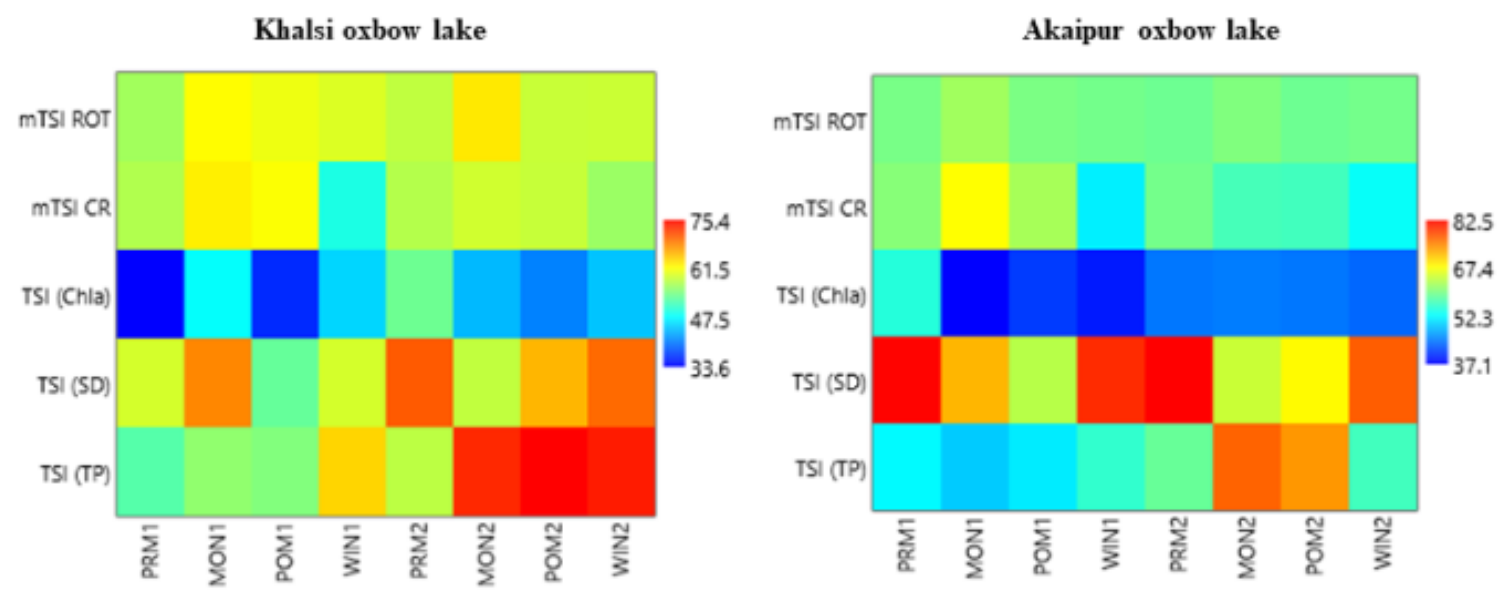

\section{Figure 4}

Temporal variation of TSI in seasonally open (Khalsi) and closed (Akaipur) oxbow lakes Note: 1: 2014-2015; 2: 2015-2016; PRM: Pre-monsoon season; MON: Monsoon season; POM: Post-monsoon season; WIN: Winter season; mTSI ROT: mean trophic status index based on Rotifer; mTSI CR: mean trophic status index based on Crustaceans; TSI (Chl a): trophic status index based on Chlorophyll a; TSI (SD): trophic status index based on sechhi depth; TSI (TP): trophic status index based on total phosporus 


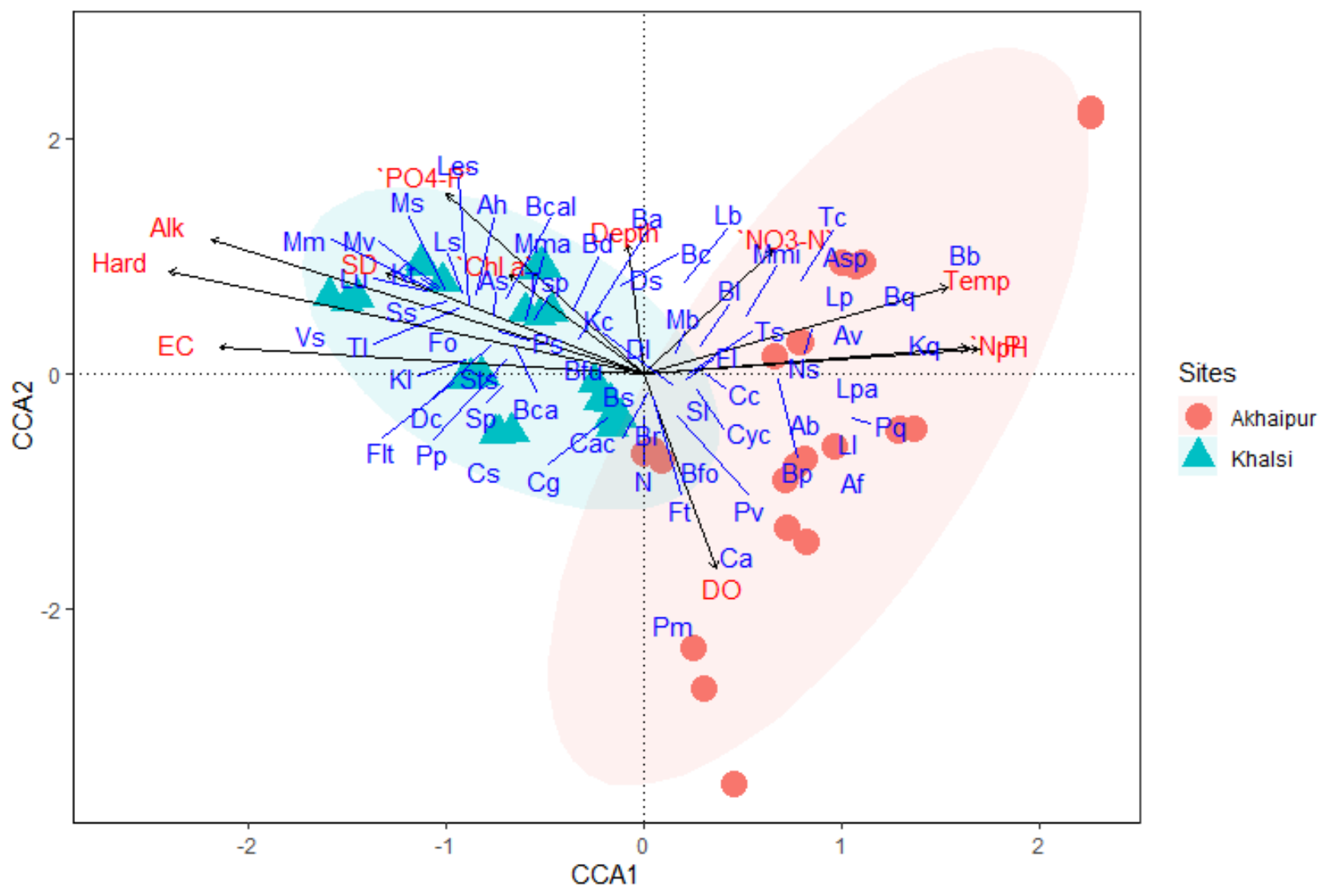

Figure 5

A canonical correspondence analysis (CCA) of zooplankton species and physicochemical parameters. SI, Scaridium lingicaudum; Pv, Polyarthra vulgaris; Pm, Polyarthra multiappendiculata; Ps, Polyarthra sp.; Fl, Filinia longispina; Ft, Filinia terminalis; Flt, Filinia longiseta; Fo, Filinia opoliensis; Ts, Trichocerca similis; TI, Trichocerca longiseta;Tc, Trichocerca cylindrical; Ts, Trichocera sp.; Af, Anuraeopsis fissa; Pp, Platyias polycanthus; Pq, Platyias quadricornis; Cg, Cephalodella gibba; Br, Brachionus rubens; Bfu, Brachionus fulcatus; Bfo, Brachionus forficula; Bb, Brachionus budapestiensis; Bc, Brachionus Calyciflurous; Bp, Brachionus patulus; Bq, Brachionus quadridentatus; $\mathrm{Bca}$, Brachionus caudatus $\mathrm{f}$. austerogenitus; Bc, Brachionus caudatus; Bd, Brachionus diversicornis; Ba, Brachionus angularis; Kc, Keratella cochlearis; Kq, Keratella quadrata; Kl, Keratella longiseta; Kt, Keratella tropica; Mm, Mytilina mucronata; Mv, Mytilina ventralis; Ms, Monostyla spp.; Lu, Lecane ungulate; Lb, Lecane bulla; Lp, Lecane ploenensis; LI, Lecane luna; Lpa, Lepadella patella; Ls, Lepadella sp; Ss, Synchaeta sp.; Ns, Notholca sp.; Ab, Asplanchna brightwelli; Ah, Asplanchna herricki; Asp, Asplanchna sp.; Bl, Bosmina longirostris; Bs, Bosmina sp.; Cc, Ceriodaphnia cornuta; Mb, Moina brachiata; Mmi, Moina micrura; Mma, Moinodaphnia macleayi; Av, Alona verrucosa; As, Alona sp.; Les, Leydigia sp.; DI, Daphnia lumhottzi; Ds, Daphnia sp.; Cyc, Cyclopoid copepod; Cac, Calanoid copepod; Cs, Cypris sp.; Sts, Stenocypris sp.; Sp, Stylonychia pustulata; Ca, Centropyxis aculeate; Dc, Diffugia corona; Vs, Vorticella sp.; Coc, Colpodia colpoda 